\title{
Bartın Üniversitesi Ulus Meslek Yüksekokulu Öğrencilerinin Okula Aidiyet Duygularında Ders Dışı Etkinliklerin Yeri ve Önemi ${ }^{1}$
}

\author{
Öğr. Gör. Ayşenur AÇIKEL* \\ Bartın Üniversitesi, Ulus Meslek Yüksekokulu, Büro Hizmetleri ve Sekreterlik Bölümü, Bartın / Türkiye, \\ aacikel@bartin.edu.tr, ORCID: 0000-0002-5528-2776 \\ Dr. Öğr. Üyesi Damla YILDIZ \\ Karabük Üniversitesi, Orman Fakültesi, Orman Mühendisliği Bölümü, Karabük / Türkiye, \\ damlayildiz@karabuk.edu.tr, ORCID: 0000-0002-6809-0538
}

\section{$\ddot{\mathbf{O} z}$}

Bu çalışmanın amacı, Bartın Üniversitesi Ulus Meslek Yüksekokulu öğrencilerinin okula aidiyet duygularında ders dişı etkinliklerin yeri ve öneminin belirlenmesidir. Araştırma tam sayım örnekleme yöntemiyle seçilmiş 36'sı kadın 90'1 erkek olmak üzere toplamda 126 öğrenciyi kapsamaktadır. Veriler araştırmacılar tarafindan geliştirilen ve dört bölümden (kişisel bilgiler, ders dışı etkinliklere katılım durumu, okula aidiyet duygusu ve ders dişı etkinliklere ilişkin likert ölçeği ile öneri ve görüşler) oluşan anket formu ile elde edilmiştir. Öğrencilerin okula aidiyet duygularını etkileyen ders dışı etkinliklere katılım sağlamaları ile öğrenci bilgilerine ait değişkenler

\footnotetext{
${ }^{1}$ Bu çalışma, 11-13 Haziran 2019 tarihinde Sinop Üniversitesi'nde düzenlenen 8. International Vocational Schools Symposium'da (8. Uluslararası Meslek Yüksekokulları Sempozyumu) bildiri olarak sunulmuş ve genişletilerek hazırlanmıştır.

* Sorumlu Yazar. Tel: +905435540553

Makale Tarih Bilgisi. Gönderim: 06.07.2020, Kabûl: 08.08.2021, Erken Görünüm: 24.11.2021, Basım: Haziran, 2023

(C) 2023. Kalem Eğitim ve Sağlık Hizmetleri Vakfı. Bütün Hakları Saklıdır. ISSN: 2146-5606, e-ISSN: 2687-6574.
} 
arasında farklılaşma olup olmadığı frekans analizi, $t$ Testi, tek yönlü varyans analizi kullanılarak tespit edilmiştir. Sonuçlara göre öğrencilerin çoğu (\%63) kendi isteği ile ders dışı etkinliklere katılmıştır. Ayrıca öğrencilerin \%88.9'u ders dışı etkinliklerin okula aidiyet duygularına katkı sağladığını düşünmektedir. Dolayısıyla ders dışı etkinlikler öğrencilerin okula aidiyet duygularında olumlu etkilere yol açmaktadır. $\mathrm{Bu}$ nedenle ögrencilerin okula aidiyet duygularının arttırılmasını sağlayacak ders dışı sosyal etkinliklere yer verilmeli ve bu duyguları geliştirici önlemler alınmalıdır. Gerçekleştirilecek ders dışı etkinlikler için öğrencilerden fikir alınmaya devam edilmesi, bu etkinliklerin belli bir plan dahilinde yapılması ve öğrencilerin kişisel gelişimlerine katkı sağlayacak kurslara katılımının desteklenmesi öğrencilerin okula aidiyet duygusuna katkı sağlayabilir.

Anahtar Kelimeler: Ulus; Meslek yüksekokulu; Okula aidiyet; Ders dışı etkinlik; Meslekî eğitim.

\title{
The Role and Significance of Extracurricular Activities of Students Sense of Belonging to School in Bartın University, Ulus Vocational School
}

\begin{abstract}
This study aims to determine the situation and importance of extra-curricular activities belonging to students' school emotions in Bartın University, Ulus Vocational School. This research was composed of 126 students (36 women and 90 men) who were selected according to the total population sampling method. Data were obtained through a questionnaire form developed by the researchers, consisting of four parts (personal information, participation in extracurricular activities, sense of belonging to school and suggestions and opinions about the Likert scale for extracurricular activities). Frequency analysis, t-Test, one-way ANOVA (Analysis of Variance) were done on datasets to determine the difference between students' participation in extracurricular activities that affect their sense of belonging to school and variables of student knowledge. Most of the students (63\%) stated that they were taking part in extracurricular activities of their own will. In addition, $88.9 \%$ of the students think that extracurricular activities positively contribute to their sense of belonging to the school. So, extracurricular activities had positive effects on students' sense of belonging to the school. Because of this reason, extracurricular social activities should be included to increase students' sense of belonging to school and, measures should be taken to improve these feelings. Keeping ideas from students for extracurricular activities, conducting these activities within a specific plan,
\end{abstract}


and supporting them for participation in courses contributing to their personal development may help sense belonging to schools.

Keywords: Ulus; Vocational school; Belonging to school; Extracurricular activities; Vocational education.

\section{Extended Summary}

Universities are higher education institutions where high-level the oretical and practical training are carried out to enable individuals to be successful in business life. In addition, it is thought that the activities carried out outside the lesson plans contribute to the students' personal development, motivation, and positive feelings for the school. Several extracurricular activities such as exhibitions, technical trips, social responsibility projects, breakfast, and similar activities have been organized in Ulus Vocational School since its inception to increase the students' academic achievement by increasing their motivation, to contribute to their professional and personal development and thus to create a sense of belonging to the school. So, it has been wondered how such activities affect students' sense of belonging to the school. The population of this study has consisted of students attending Bartın University Ulus Vocational School (UMYO) in the Spring Semester in the Academic Year of 2018-2019.

\section{Purpose}

This study aims to determine the core role and importance of extracurricular activities in UMYO students' sense of belonging to a school. Below are the research questions that are sought for answers by the purpose of the study:

1. Is there a significant difference between gender, age, department, grade, grade point average regarding the views that students participate in extracurricular activities and that extracurricular activities increase the sense of belonging to school?

2. Is there a significant difference between average monthly income and working status regarding the views that students participate in extracurricular activities and that extracurricular activities increase the sense of belonging to school?

\section{Method}

Research method including quantitative and qualitative methods was designed in this study. The screening model was used to determine perspectives and attitudes of UMYO students regarding their sense of belonging to 
school to participating in extracurricular activities. Moreover, it tested the correlation between demographic characteristics and students' participation in extracurricular activities and the other correlation parameters between belonging to the school and extracurricular activities. Complete count sampling was used as a sampling method in this study and 126 students were tested. Data were obtained through a questionnaire form created by the researchers. Found KMO value of the scale as 0.786 , and Barlett Sphericity Test result was significant and performed exploratory factor analysis. Principal Component Analysis and oblimin axis rotation technique were used to determine the structural validity of the developed scale. Pattern Matrix Item factor loads were determined as 0.30 , and five factors with eigenvalues greater than one were selected. This five-factor and 20 -item scale explain $61.437 \%$ of the total variance of the factors. Cronbach Alpha reliability coefficient of the scale was calculated as 0.87 . We used the face-to-face survey method to collect data and analysis done by SPSS 22.0 package program. Before the data collected with the questionnaire were analyzed, the normality of the data was examined, and it was determined that the data showed a normal distribution. The difference between participating in extracurricular activities that affect the participants' school belonging and tested the variables of participant information. In the case of significance was lower than 0.05 , the Tukey Test, one of the Post Hoc multiple comparison tests, was used to find out differences among groups.

\section{Results}

According to the results, most students (63\%) participated in extracurricular activities of their own will. Extracurricular activities playing a role to school belonging were as "technical trips" ( $42 \%)$, "banquets, feasts, festivals" (37\%), "social and cultural activities" (33\%), and other activities (homework, professional conversation, sports/competition) organizations, etc.), respectively. In addition, when asked to students about the reasons for participating in extracurricular activities, the most responses given were "contributing to personal development" (49\%), which were followed by "improving social relations" (46\%), "making leisure time" (44\%). According to the results of the $t$ Test and one-way analysis of variance; While there is no significant difference between "participation in extracurricular activities" and students' gender, age, GPA, there is a substantial difference between the department studied, class level, monthly average income, and working status. While there is no difference between "the state of extracurricular activities contributing to the sense of belonging to the school" and all variables, there is only a low level of 
significant difference between the departments they read. Most of the students (51.6\%, Yes and $37.3 \%$ Partly yes) stated that extracurricular activities contribute to belonging to the school.

\section{Discussion}

It was concluded that extracurricular activities increase students' belonging to the school in this study, and results were discussed with literatüre cited. According to the results, $89.7 \%$ of students participated in extracurricular activities. $63 \%$ of the participants stated that they participated in extracurricular activities voluntarily and 39\% with the recommendations from their lecturers. $88.9 \%$ of the participants gave out that extracurricular activities were important in their belonging to the school. Participants attribute more meaning to extracurricular activities as extracurricular social activities and extracurricular activities rather than activities that complement formal education. Extracurricular activities help the participants to establish a sincere and sincere communication with the lecturers, and the lecturers' allocation of time for them outside of the class hours contributes to the sense of belonging to the school. The lecturers are asked to accompany the participants in the extracurricular activities. Similar results were obtained by some studies for extracurricular activities and belonging to the school, such as Aypay, Aypay ve Demirhan, 2009; Demanet ve Van Houtte, 2012; Direkçi, Canbulat, Tezci ve Akbulut, 2020; Ekici, Bayrakdar ve Uğur, 2009; Geyik Yıldırım, 2013; Köse, 2007; Sarıer, 2016; Uslu, 2012; Yerlisi-Lapa ve Ardahan, 2009; Yeşilyurt, 2019; Yeşilyurt ve Kurt, 2012.

\section{Conclusion}

We can say that extracurricular activities have positive effects on students' belonging to the school. According to the results obtained from the study, should include social activities in extracurricular activities to increase students' belonging to the school. During the exercises, asking for ideas from students, planning them, opening lessons that will contribute to personal development, establishing good relations with students will contribute to belonging to the schools.

\section{Giriş}

Üniversiteler eğitim öğretim hizmetlerini gerçekleştiren, araştırma ve inceleme yaparak bilgi üreten ve çıktıları neticesinde topluma katkı sağlayan bir yükseköğrenim kurumudur. Eğitim ve öğretim hizmetleri ile kazandırılmaya çalışılan bilgi ve beceriler sayesinde bireyler iş hayatına daha donanımlı 
şekilde başlamaktadır. Meslek yüksekokullarında örgün eğitim veya açık öğretim yolu ile gerçekleştirilmekte olan meslekî eğitim klasik eğitim programı ile kazandırılmakta olup bu meslekî eğitimin amacı bireyin mezun olduktan sonra çalışmak istediği alanda meslekî yeterliliğe sahip olmasını sağlamaktır (Göktürk ve Aktaş, 2013).

Ders dışı etkinlikler öğretim programlarının dışında düzenlenen; sosyal, kültürel, sportif faaliyetler ile kişisel ve meslekî gelişime katkı sağlayan etkinliklerdir. Binbaşıŏlu'na (1971) göre ders dişı etkinlikler "Okulda dersler dtşında, eğitimin amaçlarına uygun olarak, öğrencilerin ilgi ve gereksinmeleri doğrultusunda, kişiliklerini geliştirmek için, okul yönetiminin bilgisi ve ögretmenin rehberliği altında yapılan planlı, programlı ve düzenli çalışmalardır." şeklinde tanımlanmaktadır. Bu anlamda ders dışı etkinlikler formel öğrenim sürecinden ayrı düşünülmemelidir. Öğrenciler ders öğrenimine katkı sağlayan teknik gezi, uygulama projesi gibi ders dışı etkinliklere katılarak formel öğretim programı sürecinde öğrendikleri teorik bilgileri uygulama ile pekiştirmektedir. Ders dışı etkinlikler de ders planları gibi planlı, programlı ve kontrollü yapılmalıdır. Öğrencilerin kişisel ve meslekî gelişimine katkı sağlayacağ veya onları motive edeceği düşünülen ders dışı etkinlikler planlanmalı ve öğrenciler bu tür etkinliklere yönlendirilmelidir (Köse, 2013).

Ders dışı etkinlikler öğrencilerin kişisel gelişimine önemli katkılar sağlamaktadır. Bu etkinliklerin özellikle öğrencilerin sosyalleşmesine, kişiler arası iletişim becerilerinin gelişmesine, ilgi duydukları alanda kendilerini geliştirmelerine, motivasyonlarının artmasına, sorumluluk duygularının gelişmesine ve kendilerine olan güvenin artmasına katkısı sağlamaktadır. (Çiftçi, 2019). Ayrıca öğrencilerin ders dışı faaliyetlere katılması onların iş birliği yaparak bir görevi birlikte yerine getirme becerilerinin gelişmesine, derste edindikleri teorik bilgileri yaparak ve yaşayarak öğrenmelerine, sorumluluk, önderlik, özgüven gibi önemli duygularının gelişmesine, kendilerini okullarına ait hissetmelerine ve dolayısıyla öğrencilerin ders başarısının ve motivasyonunun artmasına katkı sağlamaktadır (Barge, 2018).

Köse (2013) yaptığı çalışmada ders dışı etkinlikleri sınıflandırmış, benzerlik ve özelliklerine göre formel eğitimi tamamlayan etkinlikler, ders dışı sosyal etkinlikler ve okul dışı etkinlikler olmak üzere üç gruba ayırmıştır. Formel eğitimi tamamlayan etkinlikler, ders öğrenimine katkısı bulunan ev ödevi, proje, sunu hazırlama, konu anlatımı, teknik geziler vb. etkinliklerdir. Ders dış1 sosyal etkinlikler, okul kapsamında düzenlenen ancak ders saatleri ve 
içerikleri dışında düzenlenen sportif ve kültürel etkinlikler, rehberlik ve danışmanlık hizmetleri, toplantılar, törenler, sanatsal faaliyetler vb. etkinliklerdir. Okul dişı etkinlikler ise okul dişında gerçekleştirilen ev ve sokak etkinlikleri, ekonomik katkı için yapılan işler ve meslek kazanmak için yapılan etkinliklerdir.

Teorik ve uygulamalı dersler öğrencilerin meslekî bilgi ve beceri kazanmasına yardımcı olmaktadır. Eğitim-öğretimin temel amaçlarından olan etkili ve kalıcı öğrenmelerin gerçekleştirilmesi ve öğrencilerin kişiler arası ilişkilerde başarılı olması, problem çözme becerilerini kazanması ve hem kendini okullarına ait hissetmesi hem de okulunu severek eğitim alması için örgün veya meslekî eğitimden (klasik eğitim programından) daha fazlasına ihtiyaç duyulmaktadır (Yakar, 2016). Bu ihtiyacı gidermek için UMYO bünyesinde düzenlenen ders dışı etkinliklerin öğrencilerin kişisel gelişimine, yaparak-yaşayarak öğrenmesine, kişiler arası ilişkilerinin gelişmesine, işbirliği kurmasına ve okula aidiyet duygusunun oluşmasına katkı sağladığı düşünülmektedir Ayrıca ders dışı etkinlik kapsamında planlanarak gerçekleştirilen yaparak-yaşayarak öğrenme etkinlikleri, eğitimde öğrenciyi merkeze alan, keşfederek, yaşantı deneyimlerine dayanarak ve aynı zamanda öğrenmeyi sınıf dışına da taşıyarak gerçekleştirilen etkinlikler bireylerde kalıcı öğrenmeyi sağlamaktadır (Karakuş, Aksoy ve Gündüz, 2012). Goodenow (1992) okula aidiyet duygusunu "Öğrencinin kendisini okulun diğer bireyleri tarafindan ne ölçüde onaylandiğı, kabul edildiği, desteklendiği ve saygl duyulduğuna dair bireysel duygu durumu" olarak tanımlamaktadır (akt; Sarı, 2014). Öğrenciler zamanlarının büyük bir kısmını okulda geçirdiğinden öğrencilerin okulda kendilerini huzurlu, güvenli, rahat ve mutlu hissetmelerini sağlayacak fiziksel ve psikolojik düzenlemeler yapılmalıdır. Önder ve Tulunay-Ateş, (2018) öğrencinin okula aidiyet duygusu üzerinde etki eden faktörleri okulun fiziki yapısı, ders öğretimi, idari yönetim, ögretim elemanları ve arkadaşları ile olan iletişim ve iyi ilişkiler, okulda başarısının yüksek olması, öğrencinin yapılan etkinliklere katılma durumu ve isteği şeklinde ifade etmişlerdir.

Öğrencilerde okula aidiyet duygusunun oluşması, onların derslerine aktif olarak devam etmelerini, sınavlar ile genel not ortalamalarında başarıya ulaşmalarını ve okulu sevmelerini sağlayabilmektedir (Ümmet, Doğan ve Kemahlı, 2019). Okulu seven öğrenciler genel olarak arkadaşlarıyla vakit geçirmeyi, öğretim elemanları ile iletişim kurmayı, sosyal sorumluluk projelerine dahil olmayı ve okul tarafından gerçekleştirilen etkinliklere bilinçli ve istekli 
bir şekilde katılmayı tercih etmektedir (Demanet ve Van Houtte, 2012). Kendini okula ait hisseden öğrenciler, eğitimlerine daha fazla önem vermekte, s1nıf içi ve sınıf dışı etkinliklere daha fazla katılmakta, özgüven duygulalarını ve derse/okula devam oranlarını yükselmekte, öğretmen ve akranlarıyla daha iyi ilişkilere sahip olmaktadırlar (Direkçi, Canbulat, Tezci ve Akbulut, 2020). Öğrencilerin yeteri kadar okula aidiyet duygusuna sahip olamaması, yüksek derecede kaygisızlık, yalnızlık, sosyal olmayan bir hayat, sigara ve alkol kullanımı, şiddete eğilimli olma, motivasyon düşüklüğü, okula devam etmeme ve akademik başarının düşük olması gibi olumsuz durumların yaşanmasına yol açabilmektedir (Osterman, 2000; Sarı, 2012; Serbest, 2019).

Öğrencilerin okula aidiyet duygularının gelişmesi için okul yönetimi, öğretim elemanları ve öğrenci ailesinin ortak hareket etmesi gerekmektedir. Genel olarak ebeveynler üniversite tercihlerinde öğrenciye tavsiye ve görüşlerde bulunması nedeniyle önemli bir rol oynamaktadır. Ancak Türkiye'de üniversite tercihi ÖSYM (Öğrenci Seçme ve Yerleştirme Merkezi) tarafindan yapılan bir sınav neticesinde oluştuğu için bu tercih konusunda öğrenci ebeveynlerinin bir etkinliği söz konusu değildir (Yenen ve Gözlü, 2003). Bu nedenle üniversitelerde, öğrenci ailelerinin okula aidiyet duygusunun gelişiminde etkin bir rol alamadığ düşünülmektedir. Dolayısıyla okul yönetimi ve öğretim elemanları tarafindan öğrencilerin okula aidiyet duyguları geliştirilmeye çalışılmaktadır. Yükseköğretim düzeyinde öğrenci sayısında artış yaşanması, öğrenci profilinin çeşitlenmesi, öğrencilerin kazanması beklenen niteliklerin çeşitlenmesi gibi gelişmeler öğrencilere üniversitelerde sağlanan firsatların önemi konusunda çalışmaların yapılmasına neden olmuştur (İlhan, Çam ve Çam, 2018). Bu çalışmalar daha çok ödev, proje, sunum gibi ders öğrenimi tamamlayan etkinlikler ile okul tarafindan düzenlenen ve ders d1şında planlanan şenlik, konferans, panel, sempozyum, sergi, gezi, proje hazırlama vb. sosyal etkinlikler şeklinde olmaktadır (Erikçi, 2018). Öğrencilerin yüksek motivasyona sahip olmalarını, onların okula isteyerek gelmelerini, öğrenci-öğretim elemanı ve öğrenci-öğrenci ilişkilerinin güçlü olmasını, derslere aktif katılım göstermelerini ve verilen ders tamamlayıcı etkinlikleri bilinçli ve isteyerek gerçekleştirmelerini sağlayacak çeşitli etkinlikler yapılmalıdır. Bu etkinlikler gününden önce planlanmalı ve öğrencilerin yaş ve hazır bulunuşluk seviyelerine uygun olmalıdır. Ayrıca rehberlik ve danışmanlık hizmetlerinin aktif yapılması ile okul, ders, akran ve aile ilişkilerindeki problemlere çözüm aranması ögrencinin kendini değerli, önemli ve okulun bir parçası olarak hissetmesini sağlayacaktır (Saydam ve Çangal, 2018). Ders içi ve ders dış1 
etkinlikler dolaylı veya dolaysız olarak bireylerin kişisel ve meslekî gelişimine katkı sağlamaktadır. Kitap okuma etkinlikleri, kurslar, meslekî söyleşiler, teknik geziler öğrencilerin ilgilerini artırarak okudukları bölümü ve meslek yüksekokulunu sevmelerine katkı sağlayacaktır.

Kurulduğu ilk günden itibaren Ulus Meslek Yüksekokulu (UMYO)'nda hem öğrencilerin motivasyonlarını yükselterek akademik başarıları ile meslekî ve kişisel gelişimlerine katkı sağlamayı amaçlayan hem de okula aidiyet duygularını güçlendirmeye yönelik "Sözcükten çizgiye moda resim sergisi, bölüm sosyal sorumluluk projeleri, bölüm meslekî söyleşileri, teknik geziler, ilkyardım kursu, diksiyon ve bağımlılıkla mücadele kursu vb." birçok ders dışı etkinlikler yapıldığı bilinmektedir. Ayrıca, ders dışı etkinlikler öğrencilerin kişisel ve meslekî gelişimine katkı sağlaması, sosyal ilişkilerini geliştirmesi, yaparak yaşayarak ders öğrenimini arttırması ve okula aidiyet duygusuna katkı sağlaması açışından büyük önem taşımaktadır (Osterman, 2000).

\section{Çalışmanın Amacı ve Önemi}

Ders dış1 etkinliklerin bireyin çevresiyle ve arkadaşları ile ilişkilerini geliştirdiği, okul başarısını, öğrencilerin genel not ortalamasını, okula aidiyet duygusunu artırdığı birçok çalışma ile gözlenmiştir (Broh, 2002; Büküşoğlu ve Bayturan, 2005; Darling, 2005; Ekici, Bayrakdar ve Uğur, 2009; Hansen ve ark., 2003; Yılmaz, 2019). Bu çalışmaların çoğunlukla ilkokul, ortaokul ve lise öğrencilerinin ders dişı etkinlik ve okula aidiyet duygusu ile ilgili olduğu gözlenmiştir. Ancak "üniversite öğrencilerinin okula aidiyet duygularında ders dışı etkinliklerin rolü” üzerine şimdiye kadar yapılan bir çalışmaya rastlanmamış ancak ayrı başlıklar altında üniversite öğrencileri üzerinden "ders dış1 etkinlikler" ve "okula adiyet duygusu" kavramlarının incelendiği (Akkuş ve Akkuş, 2020; Alptekin, 2011; Craft, 2012; Duru ve Balkıs, 2015; İlhan ve ark., 2018; Mertoğlu, 2019; Saydam ve Çangal, 2018; Serbest, 2019; Yokuş, Ayçiçek ve Yanpar-Yelken, 2017) dikkati çekmiştir. Oysaki üniversite öğrencilerinin de okula aidiyet duygularında ders dışı etkinliklerin önemli katkısı bulunmaktadır. Ülkemizde üniversite sayısının veya üniversitelerde akademik birim ve bölüm sayılarının artarak çeşitlenmesi nedeniyle öğrenciler tercihlerini yaparken üniversite ve akademik birimlerin diğerlerinden farklı ve değerli kılacak özelliklerini de göz önünde bulundurmaktadır. Üniversitelerde hem öğrenci merkezli eğitim verilmesi hem de öğrencilerin yaparak yaşayarak öğrenmesini sağlayacak en önemli faktörlerden birisi de ders dışı etkinliklerdir. 
Üniversite yönetimlerinin sosyal kulüplere destek vermesi, kongre, konferans, gezi, konser, sosyal sorumluluk gibi faaliyetlerin gerçekleştirilmesine öncülük etmesi diğer üniversiteler arasında tercih edilebilirliği etkileyen ve öğrencilerde yüksek motivasyon sağlayarak okula aidiyet duygusunun oluşmasına destek sağlayan süreçlerdir (Alptekin, 2018). Bu çalışma ile üniversite öğrencilerinin okula aidiyet duygularının oluşmasında ders dışı etkinlerin yeri ve önemi incelenerek alanyazındaki eksikliğin giderileceği düşünülmektedir.

Bu çalışmada UMYO'da gerçekleştirilen ders dişı etkinliklerin öğrencilerin okula aidiyet duygularındaki yeri ve önemi incelenmiştir. Aynı zamanda öğrencilerin ders dışı etkinliklere katılım sağlaması, ders dışı etkinliklerin öğrencilerin okula aidiyet duygularına sağladığı katkı, öğrencilerin okula aidiyet duygularında rol oynayan ders dışı etkinlikler, öğrencilerin ders dışı etkinliklere katılma nedenleri ile öğrencilerin okula aidiyet duygusu ölçeği bulgularının değerlendirilmesi ve öğrencilerin okula aidiyet duygularını artıran ders dışı etkinliklere ilişkin görüşleri sorgulanmıştır. Ayrıca alınan görüşlerin öğrencilerin demografik bilgilerine göre değişip değişmediği istatistiksel analizler yardımıyla yorumlanmıştır.

Çalışmanın amacı, öğrencilerin okula aidiyet duygularında ders dışı etkinliklerin yerinin ve öneminin belirlenmesidir. $\mathrm{Bu}$ amaç doğrultusunda öğrencilerin okula aidiyetine ilişkin görüşleri alınmış ve ders dış1 etkinliklere katılım sağlanması ile ders dışı etkinliklerin öğrencilerin okula aidiyet duygularına sağladığı katkı, okula aidiyet üzerinde rol oynayan ders dışı etkinlikler ve ders dış1 etkinliklere katılma nedenlerine ilişkin bilgilerin farkl1lık gösterip göstermediği tespit edilmeye çalışılmıştır. Ayrıca öğrencilerin cinsiyet, yaş, okunan bölüm, aylık ortalama gelir, çalışma durumu gibi bilgilerinin ders dış1 etkinliklere katılma ve ders dışı etkinlerin okula aidiyet duygularına katkı sağlamasına ilişkin görüşleri arasında farklılık olup olmadığı yapılan istatistiksel analizler ile değerlendirilmiştir. Çalışmanın amacına uygun olarak cevap aranan araştırma soruları aşağıda yer almaktadır:

1. Öğrencilerin ders dış1 etkinliklere katılım sağlaması ve ders dışı etkinliklerin okula aidiyet duygusunu artırdığına yönelik görüşlere ilişkin cinsiyet, yaş, okunan bölüm, sınıf, genel not ortalaması arasında,

2. Öğrencilerin ders dışı etkinliklere katılım sağlaması ve ders dışı etkinliklerin okula aidiyet duygusunu artırdığına yönelik görüşlere ilişkin aylık ortalama gelir ve çalışma durumu arasında anlamlı bir farklılık var midir? 


\section{Yöntem}

Çalışmanın bu bölümünde araştırma grubu, araştırma deseni, veri toplama yöntemi, veri toplama aracı ve verilerin analizi açılanmıştır.

\section{Araştırma Modeli}

Çalışmada nicel ve nitel yöntemin birlikte kullanıldığı bir araştırma yöntemi tercih edilmiştir. UMYO öğrencilerinin okula aidiyet duygularında ders dışı etkinliklere katılma durumlarına yönelik bakış açılarını ve tutumlarını belirmek amacıyla tarama modeli kullanılmıştır. Ayrıca demografik özellikler ile ders dışı etkinliklere katılım sağlaması ve ders dışı etkinliklerin okula aidiyet duygusuna etkisi arasında ilişki olup olmadığını incelemek için ilişkisel tarama deseninden de faydalanılmıştır. Genellikle tanımlayıcı amaçlı yapılan genel tarama deseni ile katılımcıların demografik özellikleri, bir olgu/konu hakkındaki tutum ve görüşleri; ilişkisel tarama deseniyle de araştırma yapılacak evren/örneklemin değişkenleri (demografik özellikleri) ile tutum veya görüşleri arasında anlamlı bir farklılık olup olmadığını tespit edilmeye çalış1lır (Gürbüz ve Şahin, 2018).

\section{Çalışma Grubu}

Araştırmanın çalışma grubunu Bartın Üniversitesi Ulus Meslek Yüksekokulu (UMYO)'nda 2018-2019 Akademik Y1lı Bahar Yarıyılında öğrenim gören öğrenciler oluşturmaktadır. Örnekleme yoluna gidilmemiş ve tam sayım örnekleme tekniği ile UMYO'da öğrenim gören 149 öğrencinin tamamına ulaşılmaya çalışılmıştır. Veri toplama araçlarını eksik dolduran ve/veya anket içerisinde yer alan ölçekteki ifadelere hep aynı cevabı veren katılımcılar kapsam dışı bırakılmıştır. Ayrıca okula kayıtlı olup fiziksel olarak derslere devam etmeyen katılımcılara da ulaşılamamıştır. Çünkü bu katılımcılar bir yıldan uzun süredir okulda bulunmayan ve yüksekokul tarafindan düzenlenen herhangi bir ders dışı etkinliğe de katılım göstermeyen katılımcılardır. Sonuçta toplamda 126 katılımcıya anket yapılmış ve veriler 126 katılımcı üzerinden analiz edilmiştir.

Tablo 1. UMYO'da Öğrenim Gören Toplam Katılımcı Sayıları ile Anket Uygulanan Katılımcı Sayı ve Yüzdesi

\begin{tabular}{lllll}
\hline \multirow{2}{*}{ Bölüm Adı } & \multicolumn{2}{l}{ Toplam Katılımcı } & \multicolumn{2}{l}{ Ulaşılan Katılımcı } \\
\cline { 2 - 5 } & F & $\mathbf{\%}$ & F & \% \\
\hline Ormancılık & 92 & 100 & 75 & 82 \\
Büro Hizmetleri ve Sekreterlik & 49 & 100 & 45 & 92 \\
Tekstil, Giyim, Ayakkabı ve Deri & 8 & 100 & 6 & 75 \\
\hline Toplam & 149 & 100 & 126 & 85 \\
\hline
\end{tabular}


Tablo 1'de görüldüğü gibi UMYO'da 2018-2019 Akademik Y1lı Bahar Yarıyılı'nda öğrenim gören toplam 149 öğrenci bulunmaktadır. Toplam 149 öğrencinin \%85'ine (126 öğrenci) ulaş1larak bu öğrencilere anket uygulanmıştır. Ankete, Ormancılık bölümü \%82, Büro Hizmetleri ve Sekreterlik bölümü \%92 ve Tekstil, Giyim, Ayakkabı ve Deri bölümü \%75 oranında katılım sağlamıştır.

Araştırma kapsamında UMYO öğrencilerine yöneltilen sorulara ait demografik bilgiler, çeşitli değişkenlere göre tablo yardımıyla açıklanmıştır. $\mathrm{Bu}$ kapsamda incelenecek demografik değişkenler cinsiyet, yaş, okunan bölüm, sınıf, genel not ortalaması şeklindedir. Katılımcıların demografik özelliklerine ilişkin bilgiler Tablo 2'de yer almaktadır. Katılımcıların \%71'i erkek, \%29'u kadındır ve çoğu (\%79'u) 18-21 yaş aralığındadır. Ankete katılan öğrencilerin \%46'sı birinci sınıf, \%33'ü ikinci sınıf ve \%21'i uzatmalı öğrencilerdir. Kat1lımciların \%59'unun genel not ortalamas 2 'nin altında ve \%25'inin ise genel not ortalamas1 2.0-2.5 arasindadır (Tablo 2).

Tablo 2. Katılımcılara İlişkin Demografik Bilgiler

\begin{tabular}{llll}
\hline Özellikler & & Fr & $\mathbf{\%}$ \\
\hline Cinsiyet & Kadın & 36 & 29 \\
& Erkek & 90 & 71 \\
\hline Yaş Grupları & $18-21$ & 99 & 79 \\
& 22 ve üzeri & 27 & 21 \\
\hline Okunan Bölüm & Büro Hizmetleri ve Sekreterlik & 45 & 36 \\
& Ormancilı & 75 & 59 \\
& Tekstil, Giyim, Ayakkabı ve Deri & 6 & 5 \\
\hline Sınıfi & 1. sinıf & 58 & 46 \\
& 2. sınıf & 42 & 33 \\
& Uzatmalı & 26 & 21 \\
\hline Genel Not & $2.00<$ & 74 & 59 \\
Ortalaması & $2.0-2.5$ & 31 & 25 \\
& $2.5-3.0$ & 17 & 14 \\
& $3.0-3.5$ & 4 & 3 \\
\hline
\end{tabular}

Öğrencilerin ortalama aylık gelirlerinin, aylık geliri sağlama şekillerinin, çalışma durumlarının ve barınma yerlerinin ders dışı etkinliklere katılma durumlarını etkilediği düşünülmektedir. $\mathrm{Bu}$ sebeple bu değişkenlere ilişkin veriler de değerlendirilmiştir. Tablo 3 incelendiğinde ankete katılan öğrencilerin \%40'ının aylık ortalama geliri 500 TL ve altında iken, \%41'inin ise 5011000 TL arasındadır. Öğrenciler gelirlerini burs, kredi veya aile desteğinden biri veya birkaçı ile sağlayabilmektedir. Anket formunda gelir sağlama sorusuna birden fazla yanıt verdikleri göz önüne alınarak; cevaplayıcıların \%36's1nın aylık gelirini ailesinden sağladığı, \%35'inin kredi aldığ 1 ve $\% 15$ 'inin de 
gelirini çalışarak elde ettiği görülmektedir. Ankete katılan öğrencilerin \% $\% 1$ ’i herhangi bir işte çalışmadığını bildirmiştir. Çalışmakta olan öğrencilerin ise \%15'i okul dışında yarı zamanlı çalışmakta, \%12'si okul dışında tam zamanlı çalışmakta ve \%2'si de okulda yarı zamanlı çalışmaktadır. Katılımcıların $\% 67$ 'si kiralık evde, \%14'ü Ulus dışında ve \%10'u kendi evinde, \%4'ü otelde, \%4'ü öğretmenevinde ve \%2'si de akraba yanında yaşamaktadır (Tablo 3). Bu sonucun ortaya çıkmasında öğrencilerin daha çok şehir dışından gelmeleri etkili olmuştur.

Tablo 3. Katılımcıların Gelir, Çalışma Durumu, Barınma Yeri ve Burs/Kredi Durumuna İlişkin Bilgiler

\begin{tabular}{llll}
\hline Özellikler & & Fr & \% \\
\hline Aylık Ortalama & 500 TL ve altı & 50 & 40 \\
Gelir & $501-1000$ & 52 & 41 \\
& $1001-1500$ & 10 & 8 \\
& 1501 ve üzeri & 14 & 11 \\
\hline Aylık Geliri & Burs & 13 & 7 \\
Sağlama Şekli & Kredi & 66 & 35 \\
& Aile & 68 & 36 \\
& Çalışarak & 28 & 15 \\
& Yazları çalışıp birikim & 15 & 8 \\
\hline Çalışma Durumu & Çalışmıyor & 89 & 71 \\
& Okulda yarı zamanlı & 3 & 2 \\
& Okul dışında yarı zamanlı & 19 & 15 \\
& Okul dışında tam zamanlı & 15 & 12 \\
\hline Barınma Yeri & Kendi evi & 12 & 10 \\
& Kiralık ev & 84 & 67 \\
& Otel & 5 & 4 \\
& Ulus dışı & 18 & 14 \\
& Öğretmenevi & 5 & 4 \\
& Akraba yanı & 2 & 2 \\
\hline
\end{tabular}

\section{Veri Toplama Araçları}

Çalışmada veri toplama yöntemlerinden yüz yüze anket yöntemi kullanılmış ve veriler araştırmacılar tarafından hazırlanan anket formu ile elde edilmiştir. Uygulanan anket formu dört bölümden oluşmaktadır. Birinci bölümde katılımcılara ait kişisel bilgiler ve ikinci bölümde katılımcıların ders dış1 etkinliklere katılma durumuna ilişkin bilgiler sorgulanmıştır. Üçüncü bölümde okula aidiyet duygusu ile ders dışı etkinliklere ilişkin hazırlanan 5'li likert ölçeğine ve son bölümde de katılımcıların konu ile ilgili öneri ve görüşlerine yer verilmiştir. Birinci bölümdeki sorular katılımcıların genel profillerini tespit etmeye yönelik hazırlanmıştır. İkinci bölümde katılımcıların ders dış1 etkinliklere ilişkin bilgilerini almak için katografik sorulardan ve liste sorularından yararlanılmıştır. 
Üçüncü bölümde ilgili alanyazın 1şı̆̆ında (Anderman, 2002; Alptekin, 2011; Çelik, 2016; Yılmaz ve Güven, 2018) katılımcıların okula aidiyet duygusunu ve ders dış1 etkinliklere ilişkin görüşlerini sorgulayan 25 adet ölçek maddesi geliştirilmiştir. Okula Aidiyet Duygusu Ölçeği 5'li derecelendirme likert tipi bir ölçek olup derecelendirme "Kesinlikle katılmıyorum, Katılmıyorum, Kararsızım, Katılıyorum ve Kesinlikle katılıyorum" şeklinde düzenlenmiştir. Ölçek maddeleri bir örneklem üzerinde ön deneme yapılmıştır. Analiz sonuçlarına göre ders dışı etkinlik ve okula aidiyet duygusu ile ilişkili olmadığı görülen beş madde ölçekten çıkarılmıştır. Bir ölçeğin görünüşte ölçülmek istenen özelliği ölçebilmesi gerekmektedir. Bu amaçla yapılan pilot çalışma ile yakın çevreden, meslektaşlardan ve tarafsız üçüncü kişilerden ölçeğin yüzey geçerliliğini kontrol etmeleri sağlanarak ölçeğin görünüş geçerliliğini sağlamak için düzeltme ve değişiklikler yapılabilmektedir (Gürbüz ve Şahin, 2018). Nihai ölçek katılımcılara uygulanarak geçerlilik ve güvenirlik çalışmaları yapılmıştır.

Çalışma grubundan elde edilen verilerin açımlayıcı faktör analizine uygun olup olmadığı Kaiser-Meyer-Olkin (KMO) ve Barlett Testi ile test edilmiştir. KMO Test sonucunun 0.60 ve üstünde olması örneklemin faktör analizine elverişli olduğunu gösterirken Barlett Küresellik Test sonucunun da anlamlı $(p<0.05)$ olması faktör analizinin yapılabileceği anlamına gelmektedir (Büyüköztürk, 2012; Gürbüz ve Şahin, 2018). Ölçeğin KMO değeri 0.786 ve Barlett Kürsellik Test sonucu ise anlamlı $\left(\overline{\mathrm{x}}_{(190)}=883.148, p<0.05\right)$ bulunduğu için faktör analizi yapılmıştır. Geliştirilen ölçeğin yapısal geçerliliğini tespit etmek amacıyla temel bileşenler (Principal Component) analizi ve oblimin eksen döndürme tekniği kullanılmıştır. Oblimin eksen döndürme tekniği faktörlerin ilişkili olacağı varsayımı nedeniyle tercih edilmiştir (Gürbüz ve Şahin, 2018). Pattern Matrix Madde faktör yükleri 0.30 olarak belirlenmiş ve özdeğerleri 1'den büyük beş faktör tespit edilmiştir. Bu beş faktörlü 20 maddelik ölçek, faktörlerin toplam varyansının \%61.437'sini açıklamaktadır. UMYO öğrencilerinin okula aidiyet duyguları ile ders dışı etkinliklere ilişkin görüşlerini sorgulayan bu ölçekte oluşan beş faktör "okula ait genel görüşler, ders dış1 etkinliklere ilişkin görüşler, okula aidiyet duygusuna ilişkin görüşler, okul yönetimi ile öğretim elemanlarına ilişkin görüşler devamsızlık durumuna ilişkin görüşler ve genel başarı durumuna ilişkin görüşler" şeklinde isimlendirilmiş ve ölçeğin yapısal olarak geçerli olduğu görüşüne varılmıştır.

Ölçeğin güvenirliğini ortaya koymak amacıyla hesaplanan Cronbach 
Alfa güvenirlik katsayısı ise 0.87 olarak bulunmuştur. Cronbach Alfa değeri $0.80 \leq \alpha<1.00$ ise ölçek yüksek derecede güvenilir bir ölçek olarak kabul edilmektedir (Kalayc1, 2008). Buna göre Okula Aidiyet Duygusu Ölçeği’nin oldukça güvenilir olduğu söylenebilir.

Katılımcıların okula aidiyet duygularını artıran ders dışı etkinliklere yönelik öneri ve görüşlerinin yer aldığı dördüncü bölümde ise açık uçlu soruya yer verilmiş ve katılımcılardan vereceği cevapları önem derecelerine göre s1ralamaları istenmiştir.

\section{Veri Toplanması ve Analizi}

Elde edilen veriler SPSS 22.0 programına sistematik olarak girilerek analiz edilmiştir. Anket çalışmasında katılımcıların kişisel bilgileri ve sosyoekonomik durumlarına ilişkin bilgilerinin tespiti için betimsel analiz modeli kullanılmıştır. Bu modelde amaç var olan durumu ortaya koymaktır ve dolayısıyla var olan durumu ortaya koymak için kavramlaştırma ve verileri bu kavramlara yerleştirmek gerekir. Dolayısıyla bu merhale tamamlanmadan istatistiki analiz ve yorumlamalara geçilemez (Türkdoğan ve Gökçe, 2018). Birinci bölümdeki sorulara verilen cevaplardan elde edilen verilerin değerlendirilmesinde frekans analizi kullanılmıştır. Anketin üçüncü bölümünde yer alan ölçek maddeleri 5'li likert ölçeğine göre cevaplandırılmış, ölçek ifadelerine verilen cevaplar frekans analizi ile sayısallaştırılarak yorumlanmıştır.

Katılımcıların okula aidiyet duygularını etkileyen ders dışı etkinliklere ilişkin algılama düzeyleri ile katılımcı bilgilerine ait değişkenler (cinsiyet, yaş, okudukları bölüm, sınıf, genel not ortalaması, ortalama gelir ve çalışma durumu) arasında farklılaşma olup olmadığı tespit edilmeye çalışılmıştır.

Anket formu ile toplanan veriler analize tabi olmadan önce verilerin normalliğine bakılmıştır. Katılımcı bilgilerine ilişsin verilerin normalliğini belirlemek için basıklık (kurtosis) ve çarpıklık (skewness) değerlerine bakılmıştır (Tablo 4). Kurtosis ve Skewness değerleri -1.5 ile +1.5 olduğu zaman normal dağılım olduğu kabul edilmektedir (Tabachnick ve Fidell, 2013'ten akt; Gezer, 2020). Hesaplanan basıklık ve çarpıklık katsayısı değerlerinin -1.5 ile +1.5 aralığında olduğu için cinsiyet, yaş, bölüm, sınıf, genel not ortalaması, ortalama gelir ve çalışma durumu değişkenlerinin normal dağılım sergilediği kabul edilmiş olup, verilerin analizinde parametrik testlerin kullanılması tercih edilmiştir. 
Tablo 4. Değişkenlerin Normallik Testi

\begin{tabular}{llllllll}
\hline & N & Min & Max & $\overline{\mathrm{X}}$ & ss & Kurtosis & Skewness \\
\hline Cinsiyet & 126 & 1 & 2 & 1.71 & .450 & -1.096 & .960 \\
Yaş & 126 & 1 & 2 & 1.21 & .412 & -.014 & 1.409 \\
Bölüm & 126 & 1 & 3 & 1.69 & .558 & -.602 & .041 \\
Sınıf & 126 & 1 & 3 & 1.75 & .779 & 1.196 & .479 \\
Genel Not Ortalaması & 126 & 1 & 4 & 1.61 & .838 & .395 & 1.171 \\
Aylık Ortalama Gelir & 126 & 1 & 4 & 1.90 & .958 & .085 & .968 \\
Çalışma Durumu & 126 & 1 & 4 & 1.68 & 1.115 & .304 & 1.185 \\
\hline
\end{tabular}

Değişkenler arasındaki ilişkileri yorumlamak amacıyla $t$ Testi, Tek Yönlü Varyans Analizi (ANOVA) ve Post-hoc Çoklu Karş1laştırma analizinden istifade edilmiştir. Bu çoklu analizlerin tercih edilmesindeki en önemli sebep çoklu değişkenlerin (bölüm, genel ortalama, sınıf vb.) yer almasıdır. ANOVA analizi sonucunda gruplar arasında anlamlı bir fark çıkan ölçek ifadelerinde yani Sig. değeri 0.05 'ten küçük çıktığı durumlarda bu farkın hangi gruplar arasında olduğunu bulmak için Post-hoc Çoklu Karşılaştırma analizlerinden Tukey Testi yapılmıştır.

\section{Bulgular}

Çalışma ile elde edilen veriler frekans analizi, $t$ Testi, ANOVA Testi, Post-hoc Çoklu Karşılaştırma Testi gibi çeşitli analizlere tabi tutularak aşağ1daki bulgulara ulaşı1mıştır. Anket formunun birinci bölümünü oluşturan demografik özellikler yöntem bölümünde Tablo 2 ve Tablo 3 'te sunulmuştur. Anketin ikinci bölümünü oluşturan ders dışı etkinliklere katılma durumuna ilişkin bulgular ayrı ayrı değerlendirilmiş ve katılımcıların demografik özelliklerine ilişkin anlamlılık düzeyleri ölçülmüştür. Okula aidiyet duygusu ölçeğine ilişkin görüşler ile son bölümde yer alan öneri ve görüşlere ilişkin analizler ise frekans tabloları kullanılarak sunulmuştur.

\section{Katılımcıların Ders Dışı Etkinliklere Katılma Durumuna İlişkin Bulgular}

$\mathrm{Bu}$ bölümde katılımcıların ders dışı etkinliklere ne oranda katılım sağladığı, katılımcıların ders dışı etkinliklere katılmasında etkili olan faktörler, katılımcıların ders dişı etkinliklere katılma nedenleri, ders dışı etkinliklerin katılımcıların okula aidiyet duygularına sağladığı katkı ve katılımcıların okula aidiyet duygularında rol oynayan ders dışı etkinlikler açıklanmıştır. 


\section{Katılımcıların Ders Dışı Etkinliklere Katılım Sağlamasına İlişkin Bulgular}

Ankete katılan katılımcıların \%35.7'si "tüm etkinliklere katılmış" ve yarısından fazlası (\%54) yapılan ders dışı etkinliklere "kısmen katılım" göstermişlerdir. Ayrıca katılımcıların \%3.2'si etkinliklere kısmen katılmamış ve \%7.1'i de hiçbir etkinliğe katılım göstermemiştir. Buna göre katılımcılar yüksek bir oranla (\%89.7) ders dışı etkinliklere katıldığını ifade etmişlerdir.

Katılımcıların ders dışı etkinliklere katılmasında \%63'ünün kendi isteği etkili olurken, \%39'unda öğretim elemanlarının önerisi, \%19'unda merak, \%18'inde arkadaşlarının katılması ve \%8'inde diğer faktörler etkili olmuştur (Şekil 1). Katılımcılar bu soruda birden fazla seçeneği işaretlemişlerdir.

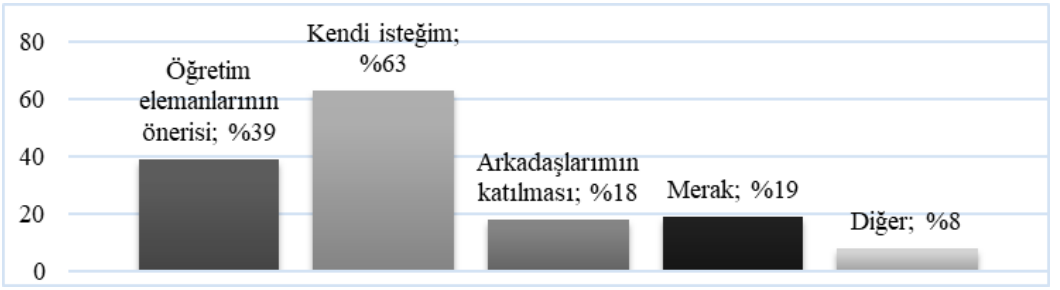

Şekil 1. Katılımcıların Ders Dışı Etkinliklere Katılmasında Etkili Olan Faktörler

Şekil 1'de görüldüğü gibi katılımcıların \%63'ü ders dış1 etkinliklere kendi isteğiyle katıldıklarını ifade etmişlerdir. Ayrıca \%39'unun ders dışı etkinliklere öğretim elemanlarının önerisi ile katıldıklarını ifade etmesi de katılımcılara ders dışı etkinlikler konusunda hem yeterli bilgi verilmesi gerektiğini hem de katılımcıların yönlendirilme ihtiyacının olduğunu göstermektedir.

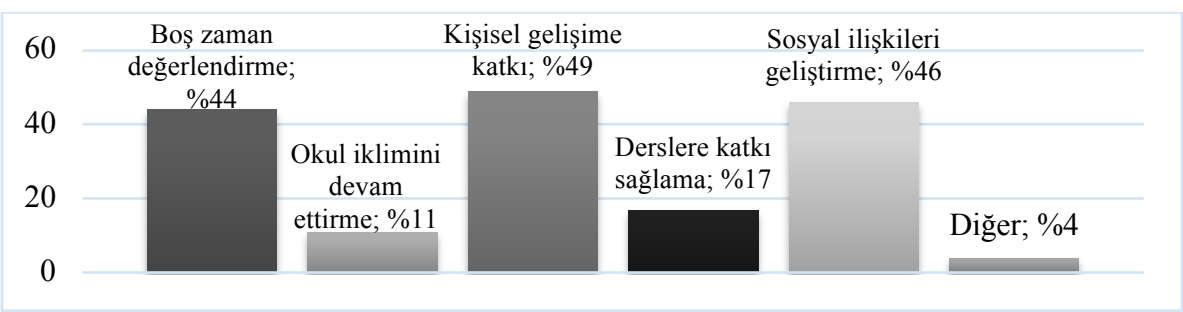

Şekil 2. Katılımcıların Ders Dışı Etkinliklere Katılma Nedeni

Katılımcılara ders dışı etkinliklere katılma nedenleri sorulduğunda birden fazla işaretleyebileceği seçenekler sunulmuştur. Buna göre ankete katılan katılımcıların \%49'u kişisel gelişimine katkı sağlamak, \%44'ü boş zamanı değerlendirmek ve \%46'sı sosyal ilişkileri geliştirmek gibi nedenlerle ders dışı 
etkinliklere katıldıklarını belirtmişlerdir. Katılımcıların sadece \%17'si derslerine katkı sağlayacağını düşündüğ için ders dışı etkinliklere katılma nedenini ifade etmiştir (Şekil 2). Dolayısıyla katılımcıların ders dış1 etkinliklere yüklediği anlamın formel eğitimi tamamlayan etkinliklerden (ev ödevi, proje, sunum vb.) öte ders dışı sosyal etkinlikler (sportif, sanatsal etkinlikler, kulüpler, toplantılar, törenler vb.) ve okul dışı etkinlikler şeklinde olduğu ifade edilebilir.

\section{Ders Dışı Etkinliklerin Katılımcıların Okula Aidiyet Duygu- suna Katkı Sağlamasına İlişkin Bulgular}

Katılımcılara ders dışı etkinliklerin okula aidiyet duygularına katkı sağlayıp sağlamadığına ilişkin yöneltilen soruya "Evet, Hayır, Kısmen Evet" seçeneklerinden biri ile cevap vermeleri istenmiştir. Görüşülenlerin \%51.6's1 ders dışı etkinliklerin okula aidiyet duygularına katkı sağladığını, \%37.3'ü kısmen katkı sağladığını ve \%11.1'i de katkı sağlamadığını düşünmektedir. Görüldüğü gibi katılımcıların \%88.9'u ders dış1 etkinliklerin okula aidiyet duygularında önemli bir yerinin olduğunu ifade etmişlerdir (Tablo 5).

Tablo 5. Ders Dışı Etkinliklerin Katılımcıların Okula Aidiyet Duygusuna Sağladığı Katk1

\begin{tabular}{llllll}
\hline & & Evet & Hayır & Kısmen Evet & Toplam \\
\hline Ders Dışı Etkinlikler Okula Olan & Fr & 65 & 14 & 47 & 126 \\
Bağlılığınıza Katkı Sağlıyor mu? & $\%$ & 51.6 & 11.1 & 37.3 & 100 \\
\hline
\end{tabular}

Okula aidiyet duygusu üzerinde rol oynayan ders dışı etkinlikler hakkında görüşleri alınan katılımcıların \%42'si teknik gezileri, \%37'si şenlik, şölen, festival vb. etkinlikleri ve \%33'ü de sosyal ve kültürel faaliyetleri önemli görmektedir. En az oranla \%16's1 ise meslekî söyleşilerin rolünden bahsetmiştir (Şekil 3). Görüldügü gibi UMYO merkezden uzak olduğu için katılımcıların toplu olarak eğlenip, vakit geçirecekleri ortamları aradığı ve istediği dikkati çekmektedir.

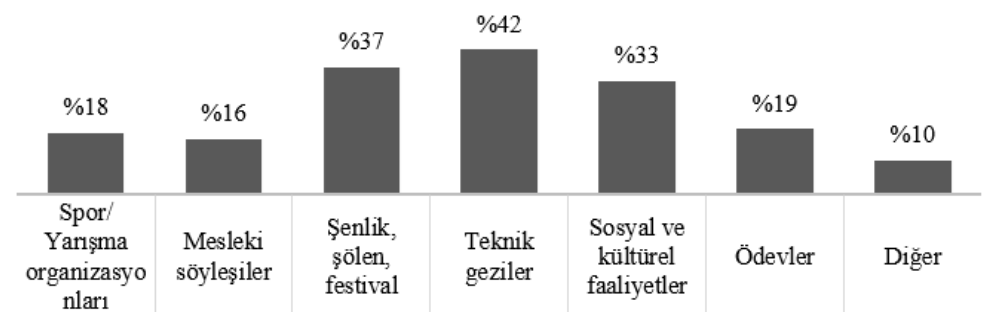

Şekil 3. Katılımcıların Okula Aidiyet Duygularında Rol Oynayan Ders Dışı Etkinlikler 


\section{Katılımcıların Demografik Bilgileri ile Ders Dışı Etkinliklere Katı- lım Sağlaması ve Okula Aidiyet Duygularına Katkı Sağlama Du- rumları Arasındaki İlişkilerin Analizi}

Bu bölümde katılımcıların cinsiyet, yaş, okunan bölüm, sınıfı, genel not ortalaması ile aylık ortalama gelir ve çalışma durumu gibi değişkenleri ile ders dışı etkinliklere katılım sağlamaları ve okula aidiyet duygularına katkı sağlama durumları arasında farklılaşma olup olmadığı tespit edilmiştir. Ancak bu analizlerde ders dışı etkinliklere katılım sağlama ve ders dışı etkinliklerin okula aidiyet duygularına katkı sağlama durumları ile demografik bilgiler arasında anlamlı farklılık bulunan değişkenler tablolaştırılırken herhangi bir farklılık bulunmayan değişkenler sadece oransal olarak yorumlanmıştır.

Katılımcıların Demografik Bilgileri ile Ders Dışı Etkinliklere Katılım Sağlaması Arasındaki İlişkilerin Analizine İlişkin Bulgular

Katılımcıların cinsiyetleri ile ders dişı etkinliklere katılım sağlaması $(\mathrm{t}=0.872, p=0.369>0.05)$ arasında anlamlı farkl1lık yoktur. Buna göre cinsiyet faktörü katılımcıların ders dışı etkinliklere katılım sağlamasında benzerlik göstermektedir. Ayrıca katılımcıların yaşı ile ders dışı etkinliklere katılım sağlamas1 $(\mathrm{F}=2.416 ; p=0.094>0.05)$ arasında anlamlı farklılık yoktur. Buna göre yaş değişkeni ders dışı etkinliklere katılım göstermede herhangi bir farklılık oluşturmamaktadır.

Tablo 6 incelendiğinde katılımcıların okudukları bölümlere göre ders dışı etkinliklere katılım sağlaması $(\mathrm{F}=5.454 ; p=0.005<0.05)$ arasında anlamlı farklılık bulunmaktadır. Bu anlamlı farklılık Tukey Testi karşılaştırılması (Tablo 7) ile analiz edilmiştir.

Tablo 6. Katılımcıların Okudukları Bölümlere Göre Ders Dışı Etkinlere Katılım Sağlamasına İlişkin Tek Yönlü Varyans Analizi

\begin{tabular}{|c|c|c|c|c|c|c|}
\hline Değișken & & $\mathbf{N}$ & $\overline{\mathrm{x}}$ & ss & $\mathbf{F}$ & Sig. \\
\hline \multirow{4}{*}{$\begin{array}{l}\text { Ders Dışı } \\
\text { Etkinliklere } \\
\text { Katılım } \\
\text { Sağlaması }\end{array}$} & $\begin{array}{l}\text { Büro Hizmetleri } \\
\text { ve Sekreterlik }\end{array}$ & 45 & 1.80 & .757 & \multirow[t]{4}{*}{5.454} & \multirow[t]{4}{*}{$.005^{*}$} \\
\hline & Ormanc1lik & 75 & 1.75 & .737 & & \\
\hline & $\begin{array}{l}\text { Tekstil, Giyim, } \\
\text { Ayakkabı ve Deri }\end{array}$ & 6 & 2.83 & 1.329 & & \\
\hline & Toplam & 126 & 1.82 & .804 & & \\
\hline
\end{tabular}

${ }^{*} p<0.05$

Tablo 7'de gösterildiği gibi Tukey Testi karşılaştırılmasına göre Tekstil, Giyim, Ayakkabı ve Deri Bölümü katılımcıları diğer bölüm katılımcılarına 
göre ders dış1 etkinliklere daha az katılım göstermiştir $(\bar{x}=2.83=$ Kısmen katıldim).

Tablo 7. Katılımcıların Okudukları Bölümlere Göre Ders Dışı Etkinlere Katılım Sağlamasına İlişkin Tukey Testi Analizi

\begin{tabular}{lllll}
\hline Değişken & (A) bölüm & (B) bölüm & $\begin{array}{l}\text { Ortalamalar } \\
\text { Farkı (A-B) }\end{array}$ & Sig. \\
\hline Ders Dışı & Büro Hizmetleri & Ormancılık & .053 & .930 \\
Etkinliklere & ve Sekreterlik & Tekstil, Giyim, Ayakkabı ve Deri & $-1.033^{*}$ & .008 \\
\cline { 2 - 5 } Katılım & Ormancılı & Büro Hizmetleri ve Sekreterlik & -.053 & .930 \\
Sağlaması & & Tekstil, Giyim, Ayakkabı ve Deri & $-1.087^{*}$ & .004 \\
\cline { 2 - 5 } & Tekstil, Giyim, & Büro Hizmetleri ve Sekreterlik & $1.033^{*}$ & .008 \\
& Ayakkabı ve Deri & Ormancılık & $1.087^{*}$ & 004 \\
\hline
\end{tabular}

Tablo 8 incelendiğinde, katılımcıların okudukları sınıf düzeylerine göre ders dışı etkinliklere katılım sağlaması $(\mathrm{F}=3.769 ; p=0.026<0.05)$ arasında anlamlı farklılık bulunmaktadır. Bu anlamlı farklılık Tukey Testi karşılaştırılması ile analiz edilmiştir (Tablo 9).

Tablo 8. Katılımcıların Okudukları Sınıf Düzeylerine Göre Ders Dışı Etkinlere Katılım Sağlamasına İlişkin Tek Yönlü Varyans Analizi

\begin{tabular}{lllllll}
\hline Değişken & & $\mathbf{N}$ & $\overline{\mathbf{X}}$ & ss & F & Sig. \\
\hline Ders Dıșı & 1. Sınıf & 58 & 1.74 & .762 & 3.769 & $.026^{*}$ \\
Etkinliklere & 2. sınıf & 42 & 1.69 & .643 & & \\
Katılım & Dönemi uzayan & 26 & 2.19 & 1.021 & & \\
Sağlaması & Toplam & 126 & 1.82 & .804 & & \\
${ }^{*} p<0.05$ & & & & &
\end{tabular}

Tablo 9'da yer alan Tukey Testi karş1laştırmasına göre dönemi uzayan katılımcılar birinci ve ikinci sınıfta okuyan katılımcılara göre ders dişı etkinliklere daha az katılım göstermiştir ( $\bar{x}=2.19=K ı$ smen katıldım). Bu duruma, dönemi uzayan katılımcıların Ulus veya Bartın'da ikamet etmemelerinin ve derslere devam zorunluluğu olmadığı için derslere katılmamalarının neden olduğu düşünülmektedir.

Tablo 9. Katılımcıların Okudukları Sınıf Düzeylerine Göre Ders Dışı Etkinlere Katılım Sağlamalarına İlişkin Tukey Testi Analizi

\begin{tabular}{lllll}
\hline Değişken & (A) Sınıf & (B) Sınıf & Ortalamalar Farkı (A-B) & Sig. \\
\hline Ders Dışı & 1. sınıf & 2. sınıf & .051 & .945 \\
\cline { 2 - 5 } $\begin{array}{l}\text { Etkinliklere } \\
\text { Katılım }\end{array}$ & & Dönemi uzayan & $-.451^{*}$ & .044 \\
\cline { 2 - 5 } \begin{tabular}{l} 
Sağlaması \\
\cline { 2 - 5 }
\end{tabular} & $2 . \operatorname{sinıf}$ & 1. sınıf & -.051 & .945 \\
\cline { 2 - 5 } & & Dönemi uzayan & $-.502^{*}$ & .031 \\
\cline { 2 - 5 } & $\begin{array}{l}\text { Dönemi } \\
\text { uzayan }\end{array}$ & 1. sınıf & $.451^{*}$ & .044 \\
\cline { 2 - 5 } & & 2. sinıf & $.502^{*}$ & .031 \\
\hline
\end{tabular}

Katılımcıların genel not ortalamaları ile ders dışı etkinliklere katılım 
sağlamas1 $(\mathrm{F}=0.142 ; p=0.935>0.05)$ arasında anlamlı farkl111k yoktur. Kat1lımcıların başarı düzeyleri ders dışı etkinliklere katılımda herhangi bir farklılık oluşturmamaktadır.

Tablo 10. Katılımcıların Aylık Ortalama Gelirlerinin Ders Dış1 Etkinlere Katılım Sağlamasına İlişkin Tek Yönlü Varyans Analizi

\begin{tabular}{|c|c|c|c|c|c|c|}
\hline \multicolumn{2}{|l|}{ Değişken } & $\mathbf{N}$ & $\overline{\mathrm{x}}$ & Ss & $\mathbf{F}$ & Sig. \\
\hline Ders Dışı Etkin- & 500 TL ve alt1 & 50 & 1.70 & .707 & 8.735 & $.000^{*}$ \\
\hline liklere Katılım & $501-1000 \mathrm{TL}$ & 52 & 1.63 & .627 & & \\
\hline \multirow[t]{3}{*}{ Sağlaması } & $1001-1500 \mathrm{TL}$ & 10 & 2.80 & .919 & & \\
\hline & 1501 TL ve üzeri & 14 & 2.21 & 1.051 & & \\
\hline & Toplam & 126 & 1.82 & .804 & & \\
\hline
\end{tabular}

${ }^{*} p<0.05$

Tablo 10 incelendiğinde, katılımcıların aylık ortalama gelirlerine göre ders dışı etkinliklere katılım sağlamaları $(\mathrm{F}=8.735 ; p=0.000<0.05)$ arasında anlamlı farklılık bulunmaktadır. Bu anlamlı farklılık Tukey Testi karşılaştırılması ile analiz edilmiştir (Tablo 11).

Tablo 11. Katılımcıların Aylık Ortalama Gelirlerine Göre Ders Dışı Etkinlere Katılım Sağlamalarına İlişkin Tukey Testi Analizi

\begin{tabular}{|c|c|c|c|c|}
\hline Değişken & (A) Gelir & (B) Gelir & Ortalamalar Farkı (A-B) & Sig. \\
\hline \multirow{12}{*}{$\begin{array}{l}\text { Ders Dışı } \\
\text { Etkinliklere } \\
\text { Katılım } \\
\text { Sağlaması }\end{array}$} & \multirow[t]{3}{*}{500 TL ve alt1 } & $501-1000 \mathrm{TL}$ & .065 & .970 \\
\hline & & $1001-1500 \mathrm{TL}$ & $-1.100^{*}$ & .000 \\
\hline & & 1501 TL ve üzeri & -.514 & .103 \\
\hline & \multirow[t]{3}{*}{$501-1000 \mathrm{TL}$} & 500 TL ve alt1 & -.065 & .970 \\
\hline & & $1001-1500 \mathrm{TL}$ & $-1.165^{*}$ & .000 \\
\hline & & 1501 TL ve üzeri & $-.580^{*}$ & .050 \\
\hline & \multirow{3}{*}{$\begin{array}{l}1001-1500 \\
\text { TL }\end{array}$} & 500 TL ve alt1 & $1.100^{*}$ & .000 \\
\hline & & $501-1000 \mathrm{TL}$ & $1.165^{*}$ & .000 \\
\hline & & $1501 \mathrm{TL}$ ve üzeri & .586 & .227 \\
\hline & \multirow{3}{*}{$\begin{array}{l}1501 \mathrm{TL} \text { ve } \\
\text { üzeri }\end{array}$} & 500 TL ve alt1 & .514 & .103 \\
\hline & & 501-1000 TL & $.580^{*}$ & .050 \\
\hline & & $1001-1500 \mathrm{TL}$ & -.586 & .227 \\
\hline
\end{tabular}

Tablo 11'de yer alan Tukey Testi karşılaştırmasına göre 1001-1500 TL aylık ortalama gelire sahip olan katılımcılar aylık ortalama geliri $1000 \mathrm{TL}$ altı olan katılımcılara göre ders dişı etkinliklere daha az katılım göstermiştir $(\overline{\mathrm{x}}=2.80=$ Kısmen katılmadım). Bu sonucun ortaya çıkmasında katılımcıların okul dışı yarı veya tam zamanlı çalışarak gelir elde etmesinin etkili olduğu söylenebilir. 
Tablo 12. Katılımcıların Çalışma Durumlarına Göre Ders Dışı Etkinlere Katılım Sağlamasına İlişkin Tek Yönlü Varyans Analizi

\begin{tabular}{lllllll}
\hline Değişken & & $\mathbf{N}$ & $\overline{\mathbf{x}}$ & ss & $\mathbf{F}$ & Sig. \\
\hline Ders Dışı & Çalışmıyorum & 89 & 1.74 & .791 & 5.251 & $.002^{*}$ \\
Etkinliklere & Okulda yarı zamanlı & 3 & 1.33 & .577 & & \\
Katılım & Okul dışında yarı zamanlı & 19 & 1.68 & .478 & & \\
Sağlaması & Okul dışında tam zamanlı & 15 & 2.53 & .915 & & \\
& Total & 126 & 1.82 & .804 & & \\
\hline
\end{tabular}

${ }^{*} p<0.05$

Tablo 12 incelendiğinde katılımcıların çalışma durumlarına göre ders dışı etkinliklere katılma durumu $(\mathrm{F}=5.251 ; p=0.002<0.05)$ arasında anlamlı farklı1ık bulunmaktadır. Bu anlamlı farklılık Tukey Testi karşılaştırılması ile analiz edilmiştir (Tablo 13).

Tablo 13. Katılımcıların Çalışma Durumlarına Göre Ders Dışı Etkinlere Katılım Sağlamalarına İlişsin Tukey Testi Analizi

\begin{tabular}{lllll}
\hline Değişken & $\begin{array}{l}\text { (A) Çalışma } \\
\text { Durumu }\end{array}$ & (B) Çalışma Durumu & $\begin{array}{l}\text { Ortalamalar } \\
\text { Farkı (A-B) }\end{array}$ & Sig. \\
\hline Ders Dışı & Çalışmıyorum & Okulda yarı zamanlı & .408 & .801 \\
Etkinliklere & & Okul dışında yarı zamanlı & .057 & .991 \\
Katılım & & Okul dışında tam zamanlı & $-.792^{*}$ & .002 \\
Sağlaması & Okulda yarı & Çalışmıyorum & -.408 & .450 \\
& zamanlı & Okul dşında yarı zamanlı & -.351 & .476 \\
& & Okul dışında tam zamanlı & -1.200 & .484 \\
\cline { 2 - 5 } & Okul dışında & Çalışmıyorum & -.057 & .991 \\
& yarı zamanlı & Okulda yarı zamanlı & .351 & .882 \\
& & Okul dışında tam zamanlı & $-.849^{*}$ & .009 \\
\cline { 2 - 5 } & Okul dışında & Çalışmıyorum & $.792^{*}$ & .002 \\
& tam zamanlı & Okulda yarı zamanlı & 1.200 & .069 \\
& & Okul dışında yarı zamanlı & $.849^{*}$ & .009 \\
\hline
\end{tabular}

Tablo 13'te yer alan Tukey Testi karşılaştırmasına göre okul dışında tam zamanlı çalışan katılımcılar ile çalışmayan katılımcılar arasında ders dışı etkinliklere katılım gösterme arasında farklılık bulunmaktadır. Bu sonucun ortaya çıkmasında katılımcıların okul dışı yarı veya tam zamanlı çalışarak gelir elde etmesinin etkili olduğu söylenebilir.

\section{Katılımcıların Demografik Bilgileri ile Okula Aidiyet Duygu-} larına Katkı Sağlama Durumları Arasındaki İlişkiler Analizine İlişkin Bulgular

Katılımcıların cinsiyetleri ile ders dış1 etkinliklerin okula aidiyet duygularına katkı sağlamasına ilişkin görüşleri $(\mathrm{t}=0.629, p=0.897>0.05)$ arasında anlamlı farklılık yoktur. Buna göre cinsiyet faktörü katılımcıların ders dışı 
etkinliklerin okula aidiyet duygularını etkileme görüşünde benzerlik göstermektedir.

Katılımcıların yaşı ile ders dışı etkinliklerin okula aidiyet duygularına katkı sağlamasına ilişkin görüşleri $(\mathrm{F}=1.305 ; p=0.275>0.05)$ arasında anlamlı farklılık yoktur. Buna göre yaş değişkeni ders dış1 etkinliklerin okula aidiyet duygularını etkileme durumlarında herhangi bir farklılık oluşturmamaktadır.

Tablo 14 incelendiğinde, katılımcıların okudukları bölümlere göre ders dış1 etkinliklerin okula aidiyet duygularına katkı sağlamasına ilişkin görüşleri $(\mathrm{F}=3.195 ; p=0.044<0.05)$ arasında düşük düzeyde farklılık bulunmaktadır. Buna göre ormancılık bölümü katılımcıları diğer bölüm katılımcılarına göre ders dışı etkinliklerin okula aidiyet duygularına katkı sağlamasına ilişkin "Evet" ( $\overline{\mathrm{X}}=1.71=$ Evet $)$ şeklinde cevap vermişlerdir. Diğer bölüm katılımcıları ise ders dışı etkinliklerin okula aidiyet duygularına katkı sağlaması durumunu "Kısmen" olarak cevaplamışlardır.

Tablo 14. Katılımcıların Okudukları Bölümlere Göre Ders Dışı Etkinliklerin Okula Aidiyet Duygularına Katkı Sağlaması Görüşüne İlişkin Tek Yönlü Varyans Analizi

\begin{tabular}{|c|c|c|c|c|c|c|}
\hline Değişken & & $\mathbf{N}$ & $\overline{\mathbf{x}}$ & Ss & $\mathbf{F}$ & Sig. \\
\hline $\begin{array}{l}\text { Ders Dışı } \\
\text { Etkinliklerin }\end{array}$ & $\begin{array}{l}\text { Büro Hizmetleri ve } \\
\text { Sekreterlik }\end{array}$ & 45 & 2.02 & .988 & \multirow{4}{*}{3.195} & \multirow{4}{*}{$.044^{*}$} \\
\hline Okula Aidiyet & Ormancilık & 75 & 1.71 & .882 & & \\
\hline $\begin{array}{l}\text { Duygularına } \\
\text { Katkı }\end{array}$ & $\begin{array}{l}\text { Tekstil, Giyim, Ayakkabı } \\
\text { ve Deri }\end{array}$ & 6 & 2.50 & .837 & & \\
\hline Sağlaması & Toplam & 126 & 1.86 & .936 & & \\
\hline
\end{tabular}

${ }^{*} p<0.05$

Tüm sınıf düzeyindeki katılımcıların ders dışı etkinliklerin okula aidiyet duygularına katkı sağlamasına ilişkin görüşleri $(\mathrm{F}=0.025 ; p=0.975<0.05)$ arasında anlamlı bir farklılık bulunmamaktadır. Buna göre katılımcılar ders dışı etkinliklerin okula aidiyet duygularını etkilemesinde benzer görüşe sahiptir. Katılımcıların genel not ortalamaları ile ders dışı etkinliklerin okula aidiyet duygularına katkı sağlamasına ilişkin görüşleri $(\mathrm{F}=1.326 ; p=0.269>0.05)$ arasında anlamlı farkl11ık yoktur. Genel not ortalamasının ders dışı etkinliklerin okula aidiyet duygusuna herhangi bir etkisinin olmadığı söylenebilir.

Katılımcıların aylık ortalama gelirleri ile ders dışı etkinliklerin okula aidiyet duygularına katkı sağlamasına ilişkin görüşleri $(\mathrm{F}=0.792$; $p=0.501<0.05$ ) arasında anlamlı bir farklılık bulunmamaktadır. Buna göre katılımcılar ders dışı etkinliklerin okula olan aidiyet duygularını etkilemesinde 
benzer görüşe sahiptir. Ancak ortalama geliri 1001 TL ve üzeri olan katılımcılar ders dışı etkinliklerin okula aidiyet duygularını etkilemesi ifadesinde "Hayır" (1001-1500 TL için $\bar{x}=2.10$ ve 1500 TL ve üzeri için $\bar{x}=2.07)$ cevabı üzerine yoğunlaşmıştır.

Katılımcıların çalışma durumları ile ders dışı etkinliklerin okula aidiyet duygularına katkı sağlamasına ilişkin görüşleri $(\mathrm{F}=0.311 ; p=0.817>0.05)$ arasında anlamlı bir farklılık bulunmamaktadır. Buna göre katılımcılar ders dışı etkinliklerin okula olan aidiyet duygularını etkilemesinde benzer görüşe sahiptir. Ancak okul dışında tam zamanlı çalışan katılımcılar ders dışı etkinliklerin okula aidiyet duygularını etkilemesi ifadesinde "Hayır" $(\overline{\mathrm{x}}=2.07)$ cevabı üzerinde yoğunlaşmıştır.

\section{Katılımcıların Okula Aidiyet Duygusu ve Ders Dışı Etkinliklere İlişkin Görüşlerinin Yorumlanması}

UMYO katılımcılarının okula aidiyet duyguları ile ders dışı etkinliklere ilişkin görüşlerinin alındığı ölçek ifadelerine verdikleri yanıtların frekans analizi sonuçları incelendiğinde:

- Katılımcıların \%50.8'i UMYO öğrencisi olduğu için kendini mutlu hissetmekte ve \%59.5'i de kendisini okulun önemli bir bireyi olarak görmektedir. Okulun genel koşullarının kendilerini geliştirmesine firsat verdiğini düşünen katılımcıların oranı \%77.2'dir. Ancak katılımcıların \%48.4'ü okulun fiziki imkanlarının ders dışı etkinlikler için uygun olduğu görüşüne katıldığını ve \%34.9'u ise kararsız kaldıklarını belirtmişlerdir.

- Katılımciların okula istekli gelip gelmemeleri okula aidiyet duyguları ile ilişkili olduğu düşünülerek "zorunlu olmadığım sürece okula gelmek istemiyorum" ifadesine yer verilmiş ve katılımcıların \%37.3'ü bu görüşe katılmadıklarını ve \%25.4'ü de kararsız kaldıklarını belirtmişlerdir. Ayrıca "devamsızlığımın en önemli nedeni kendimi okuluma ait hissetmememdir" ifadesine kat1lımcıların \%42.1'i katılmadıklarını, \%20.6'sı da kararsız kaldığını ifade etmiştir. Bu iki maddeye verilen yanıtlar değerlendirildiğinde katılımcıların ders devam durumu ve okula gelme isteklerinde dişsal faktörlerden çok kendilerini okula ait hissetmelerinden kaynaklandığı söylenebilir.

- Katılımcılara okula aidiyet duygularında okul yönetimi ile öğretim elemanlarının rolü sorulduğunda; katılımcıların \%52.3'ü okul yönetiminin ve \%73.07'si de öğretim elemanlarının okula aidiyet duygularına katkı 
sağladığını belirtmiştir. Katılımcıların bunu düşünmesinin altında yatan en önemli sebep yönetimden çok öğretim elemanları ile daha sık iletişim kurmaları ve onlara daha kolay ulaşmaları olabilir.

- Katılımcıların \%57.9'u okul başarılarında kendilerini okula ait hissetmelerinin payı olduğunu düşünmektedir. Okula aidiyet duygusunun yanında katılımcıların \%68.7'si ders dışı etkinliklerin akademik başarılarına katkı sağladığını ve \%79.4'ünün kişisel gelişimine katkı sağladığını belirtmişlerdir. Katılımcıların \%69.8'i sosyal, kültürel ve sportif etkinlikler dışında olup ders dışı etkinlikler kapsamında değerlendirilen ödevlerin (teknik gezi, görüşme, gözlem, araştırma, proje hazırlama vb.) akademik başarıyı olumlu etkilediğini düşünmektedir.

- Katılımcıların \%80.2'si ders dışı etkinliklerin öğretim elemanları ile aralarında organik bağ kurulmasına yardımcı olduğunu düşünmektedir. Ayrıca katılımcıların \%77'si öğretim elemanlarının ders saati dışında onlara vakit ayırmasının okula olan aidiyet duygularına katkı sağladığını ve \%73.1'i de öğretim elemanlarının ders dışı etkinliklere katılmaları gerektiğini düşünmektedir.

- Katılımcıların \%52.4'ü ders dışı etkinlikler anlamında okul yönetiminin katılımcıların beklentilerini karşıladığını ve \%76.2'si de ders dışı etkinliklerin verimli şekilde yürütülmesinde okul yönetiminin büyük katk1sının bulunduğunu belirtmişlerdir. Ayrıca katılımcıların \%88.9'u ders dışı etkinliklerin planlanmasında katılımcıların fikrinin alınmasının onları mutlu ettiğini düşünmektedir.

- Katılımcıların \%73.8'i ders dışı etkinler sayesinde diğer bölüm arkadaşları ile kaynaşma imkanı bulduklarını düşünmektedir.

- Katılımcılar "Yapılması düşünülen etkinliklerin önceden duyurulmaması katılımcıların katılma isteğini olumsuz etkilemektedir" şeklinde yöneltilen ifadeye \%45.2'si katıldıklarını, \%28.6'sı da kararsız kaldıklarını belirtmişlerdir.

\section{Katılımcıların Öneri ve Görüşlerinin Yorumlanması}

Katılımcıların "Okula aidiyet duygunuzu artıracağını düşündüğünüz en önemli 3 ders dışı etkinliği önceliklendirerek belirtiniz." şeklindeki soruya verdikleri cevapların 1, 2 ve 3. öncelik sırasına göre kullanma sıklıkları (frekansları) Tablo 15'te yorumlanmıştır. Katılımcılar 1. önceliklerinde 91 ifade, 2. önceliklerinde 73 ifade ve 3 . önceliklerinde 55 ifade olmak üzere toplamda 219 ifadeye yer vermişlerdir. Anketlerden elde edilen yanıtlar temel alınd1ğında katılımcıların önceliklerine verdikleri cevapların toplamı sırası ile 1) 
gezi (38 kez), 2) gezi (20 kez), 3) şenlik, şölen, festival, konser vb. faaliyetler (15 kez) şeklinde olmuştur.

Tablo 15. Katılımcıların Okula Aidiyet Duygularını Artıran Ders Dışı Etkinlikler

\begin{tabular}{lllll}
\hline Okula Aidiyet Duygusunu & \multicolumn{3}{c}{ Sıklık (Frekans) } & Toplam \\
\cline { 2 - 5 } Artıran Ders Dışı Etkinlik Adı & $\mathbf{1 . ~ o ̈ n c e l i k ~}$ & $\mathbf{2 . ~ o ̈ n c e l i k ~}$ & 3. öncelik \\
\hline Gezi & 38 & 20 & 9 & 67 \\
Doğa yürüyüşü & 1 & 1 & 3 & 5 \\
Meslekî söyleşi & 6 & 7 & 5 & 18 \\
Ödev & 8 & 0 & 1 & 9 \\
Sosyal ve kültürel faaliyetler & 8 & 13 & 10 & 31 \\
Sportif faaliyetler & 15 & 7 & 7 & 29 \\
Şenlik, şölen, festival, konser vb. & 11 & 13 & 15 & 39 \\
Uygulamalı ders & 3 & 5 & 3 & 11 \\
Yarışma organizasyonları & 1 & 7 & 2 & 10 \\
\hline Toplam & 91 & 73 & 55 & 219 \\
\hline
\end{tabular}

Tablo 15’te görüldüğü gibi katılımcıların;

- Birinci öncelikleri gezi (38 kez), sportif faaliyetler (15 kez) ve şenlik, şölen, festival, konser vb. etkinlikler (11 kez) şeklinde,

- İkinci öncelikleri gezi (20 kez), sosyal ve kültürel faaliyetler (13 kez), şenlik, şölen, festival, konser vb. etkinlikler (13 kez), meslekî söyleşi (7 kez), yarışma organizasyonları (7 kez), sportif faaliyetler (7 kez) şeklinde,

- Üçüncü öncelikleri ise şenlik, şölen, festival, konser vb. etkinlikler (15 kez), sosyal ve kültürel faaliyetler (10 kez) ve gezi (9 kez) şeklinde s1ralanmıştır. Görüldüğü gibi katılımcılar genel olarak eğlenebilecekleri ve arkadaşları ile vakit geçirebilecekleri etkinlikleri tercih etmekte ve bu tür etkinliklerin onların okula aidiyet duygularında önemli bir yerinin olduğunu düşünmektedir.

\section{Sonuç ve Tartışma}

Bartın Üniversitesi Ulus Meslek Yüksekokulu özelinde yürütülen bu çalışma kapsamında katılımcıların okula aidiyet duygularında ders dış1 etkinliklerin yeri ve önemi belirlenmeye çalışılmıştır. Çalışma sonucunda ders dışı etkinliklerin öğrencilerin okula aidiyet duygularını artırmada önemli bir yerinin olduğu ve bu duyguyu daha da artıracak ders dışı etkinliklere ağırlık verilmesi gerektiği düşünülmektedir. Anketler sonucu elde edilen veriler de değerlendirilip yorumlandığında üzerinde durulan bu konunun desteklendiği görülmüşsür. Yapılan çalışmada aşağıdaki sonuçlara ulaşılmış ve tartışılmıştır: 
Toplam 149 öğrencinin \%85'ine denk gelen 126 öğrenciye anket uygulanmıştır. Bu öğrencilerin \%71'i erkek, \%29'u kadındır. Genel olarak yaş ortalaması 18-21 yaş aralığındadır. Katılımcıların \%46'sı 1. sınıfta, \%33'ü 2. sınıfta öğrenim görmekte olup, \%21'i de dönemi uzayan öğrencilerden oluşmaktadır.

Katılımcıların \%89.7'si ders dışı etkinliklere katıldığını ifade etmiştir. Katılımcıların \%63'ü ders dışı etkinliklere kendi isteği ile ve \%39'u da öğretim elemanının önerisi ile katılım gösterdiğini bildirmiştir. Katılımcıların ders dış1 etkinliklere kendi isteği ile katılmak istemesi okula olan aidiyet duygusunu göstermektedir. Benzer şekilde Köse (2007) çalışmasında, öğrencilerin \%51'inin ders dışı etkinliklere kendi istekleri ile katıldıklarını ortaya koymuştur. Bu durum, öğrencilerin ders dışı etkinlikleri başkalarının etkisinde kalmadan kendi bireysel isteklerinin ön planda olmasıyla ve bilinçli olarak seçtiğini göstermektedir. Bu anlamda onların ilgisini çeken, sevdikleri, istedikleri ders dışı etkinliklerin planlanması için çalışılması gerekmektedir.

Katılımcıların \%88.9'u ders dişı etkinliklerin okula aidiyet duygularında önemli bir yerinin olduğunu ifade ederken, sadece \%11.1'i katkı sağlama konusuna olumsuz bakmaktadır. Görüldüğü gibi öğrencilerin okula aidiyetleri yüksektir ve bunda ders dışı etkinlikler ve bu ders dış1 etkinlikleri yürüten okul yönetimi ile öğretim elemanlarının rolü büyüktür. Geyik-Yıldırım (2013) çalışmasında, MYO’larda öğrenim gören öğrencilerin en büyük ve önemli sorununun aidiyet duygusu olduğunu iddia etmektedir. Düzenli olarak yapabilecek sosyal aktiviteler, geniş arşivli kütüphane, yerel ölçekli spor tesisleri, sanatsal ve kültürel etkinlikler vb. uygulamalar MYO öğrencilerinin aidiyet duygusunu güçlendirecek etkenler olarak görülmektedir. Çalışmamızda öğrencilerin büyük çoğunluğunun ders dışı etkinliklerin okula aidiyet duygularındaki yerini yüksek görmeleri ders dışı etkinliklerin okula aidiyet sorununu çözmede kilit rol oynadığını düşündürmektedir.

Ankete katılan katılımcıların okula aidiyet duyguları üzerinde rol oynayan ders dışı etkinlikler sırasıyla, teknik geziler: enlik, şölen, festival vb etkinlikler ile sosyal ve kültürel faaliyetler şeklindedir. Ekici, Bayrakdar ve Uğur (2009)'un ortaöğretim kurumlarındaki yönetici ve öğrencilerinin ders dış1 etkinliklere ilişkin görüşlerinin incelediği çalışmada hem yöneticiler hem de öğrenciler tarafından tercih edilen ders dışı etkinlikler \%49.5 oranında spor ve yarışma organizasyonları, \%35.4 oranında şenlik, şölen, festival olarak ortaya çıkmıştır. Üniversite öğrencilerinin teknik gezileri okula aidiyette rol 
oynayan ders dışı etkinlik olarak ilk sıraya koymalarındaki sebep teoride öğrendiklerini gezi, gözlem ve uygulamalar ile pratiğe dökme ve pekiştirme imkânı bulmaları ve yaparak-yaşayarak öğrenmenin daha kalıcı öğrenme sağladığını düşünmeleri olabilir.

Katılımcılar ders dışı etkinliklere formel eğitimi tamamlayan etkinliklerden daha çok ders dışı sosyal etkinlikler ve okul dışı etkinlikler olarak anlam yüklemektedir. Ankete katılan öğrencilerin kişisel gelişimlerine katkı sağlamak, boş zamanı değerlendirmek ve sosyal ilişkileri geliştirmek gibi nedenlerle ders dışı etkinliklere katıldıklarını belirtmesi ve sadece \%17'sinin derslerine katkı sağlayacağını düşündüğü için ders dışı etkinliklere katıldıklarını belirtmesi bu durumun önemli bir göstergesidir. Yerlisi-Lapa ve Ardahan (2009) tarafından yapılan çalışmada benzer şekilde üniversite öğrencileri ders dış1 aktivitelere katılırken eğlenmek, arkadaşlarıyla birlikte olmak, rahatlamak ve yeni şeyler öğrenmek gibi nedenleri belirtmişlerdir. Dolayısıyla öğrenciler kendilerini mutlu hissedecekleri etkinlikleri daha çok tercih ettiklerini ifade etmişlerdir.

Katılımcıların ders dışı etkinliklere katılım sağlamaları cinsiyet, yaş ve genel not ortalamalarından bağımsız ancak okunan bölüm, sınıf düzeyi, aylık ortalama gelir ve çalışma durumları ile ilişkilidir.

Ders dışı etkinliklerin katılımcıların okula aidiyet duygularını etkileme durumları yaş, cinsiyet, sınıf düzeyi, genel not ortalamaları, aylık ortalama gelir ve çalışma durumlarından bağımsız ancak okunan bölüm ile ilişkilidir.

Katılımcılar UMYO öğrencisi olduğu için kendini mutlu hissetmekte ve kendini okulun önemli bir bireyi olarak görmektedir. Ayrıca katılımcıların ders devam durumu ve okula gelme isteklerinde kendilerini okula ait hissetmelerinin payı bulunmaktadır. Uslu (2012) çalışmasında etkili bir ekip çalışmasına sahip okul toplumunun, öğrencilerin kendilerini okula ait hissetmelerinde etkili olacağını bildirmiştir. Ayrıca okulunda mutlu olan, kendini okulun parçası hisseden ve okulunda olumlu bir iklimin olduğunu düşünen öğrencilerin okul aidiyet düzeylerinin yüksek olduğunu da iddia etmektedir.

Katılımcıların okul başarılarında kendilerini okula ait hissetmelerinin etkisi bulunmakta ve ders dışı etkinlikler akademik başarılarına ve kişisel gelişimlerine katkı sağlamaktadır. Sarıer (2016) yaptığı çalışmada okul müdürlerinin etkin liderlik göstererek ve öğrencinin gelişimine katkıda bulunacak öğrenme ortamları oluşturarak etkili olmalarının ve güçlü bir okul kültürü 
oluşturmalarının katılımcıların okula bağlanmalarına etkisi olduğunu ve bunun sonucunda da katılımcının akademik başarısının yükseldiğini ifade etmiştir.

Ders dışı etkinlikler katılımcıların öğretim elemanları ile aralarında samimi ve içten etkili bir iletişim kurulmasına yardımcı olmakta öğretim elemanlarının ders saati dışında onlara vakit ayırması okula olan aidiyet duygularına katkı sağlamakta olup öğretim elemanlarının ders dışı etkinliklerde kat1lımcıların eşlik etmesi istenmektedir. Benzer şekilde Aypay, Aypay ve Demirhan (2009) çalışmalarında, öğrencilerin öğretim elemanlarıyla ders dış1 sosyal ilişkiler kurmalarının onların üniversiteye olan aidiyet duygularıyla ilişkili olduğunu gösterdiğini iddia etmektedir. Ayrıca Yeşilyurt (2019) eğitim fakültesi lisans programları ders öğrenme çıktılarının kazanımını etkileyen değişkenlerin etkisi ve nedenleri üzerine yaptığı bir araştırmada öğrencilerin dersin çıktılarının kazanımında dersin yürütücü öğretim elemanın iletişim eksikliğinin olması, tüm sorumluluğu öğrenciye bırakarak yeterince ilgi göstermemesinin olumsuz yönde etkilediği ifade edilmektedir. Görüldüğü gibi öğrencide olumlu algı oluşması için hem ders esnasında hem de ders dışı etkinliklerde öğretim elemanlarının öğrenci ile etkileşimi önem arz etmektedir.

UMYO yönetiminin ve akademik personelinin, eğitimin önemli bir parçası olan ders dışı etkinlik kavramına önem vermesi gerektiği ve bu konunun öğrencilerin okula aidiyet duygularını artırmada önemli bir rol oynadığ 1 dikkati çekmektedir. Araştırma sonuçlarımıza paralel şekilde Uslu (2012) çalışmasında öğrencilerin öğretmenleriyle kurduğu olumlu ilişkilerin öğrencilerin okula aidiyetleri üzerinde belirleyici rol oynadığını ifade etmiştir.

Katılımcılar, okula aidiyet duygularını artıracağını düşündüğü en önemli 3 ders dışı etkinliği öncelik sırasına göre; birinci öncelik gezi, ikinci öncelik gezi ve üçüncü öncelik şenlik, şölen, festival, konser vb. faaliyetler olarak sıralamıştır. Benzer sonuçların tespit edildiği Yeşilyurt ve Kurt (2012)'un değerleri kazandırmasındaki etkililik açısından resmî ve örtük program ile okul dişı etmenlerin öğrenci görüşleri doğrultusunda değerlendirilmesi çalışmasında öğrencilerin ortak görüş olarak sunduğu ve değerlerin kazandırılmasında önemli faktörler olarak sıralanan okul dış1 etmenler; bilgispor yarışmaları, sanat etkinlikleri gibi okullar arası ilişkiler ile sohbet, tartışma oyun gibi okul arkadaşlarıyla sosyal ilişkiler olmuştur. 


\section{Öneriler}

Çalışma kapsamında ulaşılan sonuçlardan, gözlemlerden ve katılımcı görüşlerinden yola çıkarak geliştirilen bazı öneriler şunlardır:

1. Ders dış1 etkinlikler çeşitlendirilebilir. Özellikle katılımcıların okula aidiyetlerinde önemli rol oynayan ve katılımcıların beklentileri arasında olan ders dışı sosyal etkinliklere (gezi, sportif, sanatsal etkinlikler, kulüpler, toplantılar, törenler vb) daha çok ağırlık verilmelidir.

2. Katılımcıların okula aidiyet duygularını geliştirici önlemler alınabilir. Bu konuda özellikle UMYO fiziksel yapı ve donanım bakımından desteklenebilir. Ayrıca düzenlenen sosyal ve kültürel etkinliklerin nitelik ve nicelik olarak geliştirilmesi ile katılımcıların okula aidiyet duyguları arttırılabilir.

3. Alanyazında bazı üniversitelerde "Ders Dışı Etkinlik Dersi Yönergesi" olduğu dikkati çekmiştir (Aksaray Üniversitesi, 2017; İstanbul Gedik Üniversitesi, 2021; Yozgat Bozok Üniversitesi, 2018). UMYO'da bu uygulamanın yer alıp alamayacağı ile ilgili araştırma yapılabilir. Ders dışı etkinlikler seçmeli ders olarak bütün bölümlerdeki öğretim planlarında yer alabilir.

Bu çalışma, Bartın Üniversitesi Ulus Meslek Yüksekokulu'nda yapılmıştır. Benzer nitelikte çalışmaların Bartın Üniversitesi'nin diğer farklı birimlerinde hatta başka üniversitelerde yapılması, üniversite öğrencilerinin okula aidiyet duygularında ders dışı etkinliklerin yeri ve öneminin belirlenmesinde etkili olacaktır. $\mathrm{Bu}$ çalışmanın periyodik aralıklarla tekrarlanması ve yaşanan değişimlerin izlenmesi faydalı görülmektedir. Bu nedenle benzer nitelikte yapılacak çalışmalara ihtiyaç vardır.

\section{Kaynakça}

Akkuş, Ç. ve Akkuş, G. (2020). Türk dünyası öğrencilerinin aidiyet duygularının akademik başarılarına etkisinde sosyalleşmenin aracılık rolü. Türk Dünyası İncelemeleri Dergisi, 20(2), 355-382.

https://dergipark.org.tr/tr/pub/egetdid/issue/58630/825731

Aksaray Üniversitesi. (2017) Aksaray Üniversitesi ders dişı etkinlik dersi yönergesi. http://ogris.aksaray.edu.tr/files/yonetmelikler/ASU_Ders_disi_etkinlik_yonergesi.pdf

Alptekin, D. (2011). Toplumsal aidiyet ve gençlik: Üniversite gençliğinin aidiyeti üzerine sosyolojik bir araştırma. Yayımlanmamış doktora tezi, Selçuk Üniversitesi Sosyal Bilimler Enstitüsü.

Anderman, E. M. (2002). School effects on psychological outcomes during adolescence. Journal of Educational Psychology, 94(4), 795-809. 
Aypay, A., Aypay, A. ve Demirhan, G. (2009). Öğrencilerin üniversiteye sosyal uуumu bir üniversite örneği. Uşak Üniversitesi Sosyal Bilimler Dergisi, 2(1), 46-64.

Barge, M. A. (2018). What are extracurricular activities and why do you need them. https://blog.prepscholar.com/what-are-extracurricular-activities-and-why-doyou-need-them

Binbaşığlu, C. (1971). Ders dışı etkinliklerin niteliği, önemi ve değeri. Ĕgitim Hareketleri, 17(194-195), 16-18.

Broh, B. A. (2002). Linking extracurricular programming to academic achievement: who benefits and why? Sociology of Education, 75(1), 69-95.

Büküşoğlu, N. ve Bayturan, A. F. (2005). Serbest zaman etkinliklerinin gençlerin psiko-sosyal durumlarına ilişsin algısı üzerindeki rolü. Ege Tip Dergisi, 44(3), 173-177.

Büyüköztürk, Ş. (2012). Sosyal bilimler için veri analizi el kitabl: İstatistik, araştırma deseni, SPSS uygulamalart ve yorum (17. bask1). Ankara: Pegem Akademi Yayinları.

Craft, S. W. (2012). The impact of extracurricular activities on student achievement at the high school level. Yayımlanmamıs doktora tezi, University of Southern Mississippi.

https://aquila.usm.edu/dissertations/543

Çelik, M. (2016). Ortaokul öğrencilerinin ders dışı sportif faaliyetlere katılım düzeyleri ve sorunları (Burdur örneği). Uluslararası Spor Bilimleri Dergisi, 2(2), 2836.

Çiftçi, Y. E. (2019). Serbest etkinlik uygulamalarının sınıf öğretmenlerinin görüşlerine göre değerlendirilmesi. Yayımlanmamış yüksek lisans tezi, Siirt Üniversitesi Sosyal Bilimler Enstitüsü.

Darling, N. (2005). Participation in extracurricular activities and adolescent adjustment: Cross-sectional and longitudinal findings. Journal of Youth and Adolescence, 34(5), 493-505.

Demanet, J. ve Van Houtte, M. (2012). School belonging and school misconduct: The differing role of teacher and peer attachment. Journal of Youth and Adolescence, 41(4), 499-514.

Doi: $10.1007 / \mathrm{s} 10964-011-9674-2$.

Direkçi, B., Canbulat, M., Tezci, I. H. ve Akbulut, S. (2020). The psychometric properties of school belonging scale for middle school students. International Journal of Assessment Tools in Education, 2, 159-176.

Doi: $10.21449 /$ ijate. 723386

Duru, E. ve Balkıs, M. (2015). Birey-çevre uyumu, aidiyet duygusu, akademik doyum ve akademik başarı arasındaki ilişkilerin analizi. Ege Eğitim Dergisi, 16(1), 122-141.

Ekici, S., Bayrakdar, A. ve Ugur, A. O. (2009). Ortaöğretim kurumlarındaki yöneticilerin ve öğrencilerin ders dışı etkinliklere bakış açılarının incelenmesi. Uluslararast Insan Bilimleri Dergisi, 6(1), 430-444.

Erikçi, B. (2018). Okullarda ders dişı etkinliklerin işlevleri. https://tedmem.org/blog/okullarda-ders-disi-etkinliklerin-islevleri.

Geyik Yıldırım, S. (2013). Doğu Anadolu Bölgesi'ndeki meslek yüksekokullarında okuyan öğrencilerin sorunları (Kağızman MYO öğrencileri örneği). Electronic 
Journal of Vocational Colleges, UMYOS Özel Sayı/Aralı, 59-66.

Goodenow, C. (1992). School motivation, engagement, and sense of belonging among urban adolescent students. Annual Meeting of the American Educational Research Association'da sunulan bildiri, San Francisco, CA.

Göktürk, İ. E. ve Aktaş, A. (2013). Sosyal bilimler meslek yüksekokullarının eğitim sürecinde; uygulama açısından karşılaşılan sorunlar ve çözüm önerileri. Electronic Journal of Vocational Colleges, UMYOS Özel Sayl/Aralı, 1-8.

Gürbüz, S. ve Şahin, F. (2018). Sosyal bilimlerde araştırma yöntemi (5. baskı). Ankara: Seçkin Yayınevi.

Hansen, D. M., Larson, R. W. ve Dworkin, J. B. (2003). What adolescents learn in organized youth activities: A survey of self-reported developmental experiences. Journal of Research on Adolescence, 13(1), 25-55.

İlhan, E., Çam, S. Ş. ve Çam, Z. (2018). Yükseköğretimde öğrencilerin akademik, sosyal ve kültürel faaliyetlere etkin katılımı. Türk Eğitim Bilimleri Dergisi, $16(2), 213-234$.

İstanbul Gedik Üniversitesi (2021). Ístanbul Gedik Üniversitesi ders dışı etkinlikler uygulama esaslart. https://kms.kaysis.gov.tr/Home/Kurum/71457743

Kalayc1, Ş. (2008). SPSS uygulamalı çok değişkenli istatistik teknik. Ankara: Asil Yayın Dağıtım Ltd. Şti.

Karakuş, U., Aksoy, B. ve Gündüz, İ. (2012). Dokuzuncu sınıf coğrafya derslerinde ders dış1 etkinliklerin öğretmen görüşlerine göre değerlendirilmesi. Gazi Üniversitesi Gazi Eğitim Fakültesi Dergisi, 32(2), 489-513.

Köse, E. (2007). İlköğretim öğrencilerinin ders dişı etkinliklerini tercih etme nedenleri. A. Ü. Bayburt Ĕ̆itim Fakültesi Dergisi, 2(3), 46-61.

Köse, E. (2013). Eğitim kurumlarında gerçekleştirilen ders dışı etkinliklerin sınıflandırılmasına yönelik bir öneri. Uluslararası Türkçe Edebiyat Kültür Eğitim Dergisi, 2(2), 336-353.

Mertoğlu, H. (2019). Fen bilgisi öğretmen adaylarının farklı öğrenme ortamlarında gerçekleştirdikleri okul dişı etkinliklere ilişkin görüşleri. İnformal Ortamlarda Araştırmalar Dergisi, 4(1), 37-60.

Osterman, K. F. (2000). Students' need for belonging in the school community. Review of Educational Research, 70(3), 323-367.

Doi: 10.3102/00346543070003323

Önder, E. ve Tulunay Ateş, Ö. (2018). Sınıf tekrarı yapan ve yapmayan öğrencilerde okul aidiyeti. 13. Uluslararası Ĕgitim Yönetimi Kongresi Ĕgitim Yönetimi Araştırmaları E-Kitabı, 156-166.

https://rive.google.com/file/d/1v0328n1m4W6DLJlcayugOzVElv-NuJcf/view

Sarı, M. (2012). Ortaöğretim kurumlarındaki yöneticilerin ve öğrencilerin ders dışı etkinliklere bakış açılarının incelenmesi. Kuramsal Ĕ̆itim Bilim Dergisi, 5(1), $72-89$.

Sarı, M. (2014). Ortaokul öğrencilerinde okula aidiyet duygusu ve empatik sınıf atmosferi algısı. Gaziantep Üniversitesi Sosyal Bilimler Dergisi, 13(2), 479-492.

Sarıer, Y. (2016). Türkiye' de öğrencilerin akademik başarısını etkileyen faktörler: Bir meta-analiz çalışması. Hacettepe Üniversitesi Eğitim Fakültesi Dergisi, 31(3), 609-627.

Saydam, M. ve Çangal, Ö. (2018). Yabancılara Türkçe öğretiminde etkin katılımlı 
ders dışı etkinliklerin öğrenci motivasyonuna etkisi. Kuramsal Eğitim Bilim Dergisi, 11(2), 342-358.

Serbest, Ö. (2019). Okul takımlarında görev alan lise ögrencilerinin okul aidiyet duygularının incelenmesi. Yayımlanmamış yüksek lisans tezi, Trabzon Üniversitesi Lisansüstü Eğitim Enstitüsü Beden Eğitimi ve Spor Anabilim Dalı.

Türkdoğan, O. ve Gökçe, O. (2018). Sosyal bilimlerde araştırma yöntemi (3. baskı). Konya: Çizgi Kitabevi.

Uslu, F. (2012). Ilköğretim okulu öğrencilerinin okula yönelik aidiyeti: öğretmen-öğrenci ilişkisi, akran ilişkisi ve aile katılımının rolü. Yayımlanmamış yüksek lisans tezi, Mersin Üniversitesi Eğitim Bilimleri Enstitüsü Eğitim Bilimleri Anabilim Dalı.

Ümmet, D., Doğan, S. ve Kemahlı, H. P. (2019). Lise öğrencilerinin okula aidiyet duyguları ve sosyal iyi oluşları üzerine karma bir araştırma. OPUS Uluslararası Toplum Araştırmaları Dergisi, 10(17), 1625-1663.

Doi: 10.26466/opus.517176

Yakar, A. (2016). Geleceğin eğitimi üzerine program ve tasarım modeli önerileri: “yaşamsal eğitim programları" ve "yaşamsal öğretim tasarımları”. Muğla Sitkı Kocaman Üniversitesi Ĕgitim Fakültesi Dergisi, 3(2), 1-15.

Yenen, V. Z. ve Gözlü, S. (2003). Yüksek öğretimde müşteri beklentileri: Türkiye'den örnekler. ITÜ Dergisi, 2(2), 28-38.

Yerlisi Lapa, T. ve Ardahan, F. (2009). Akdeniz üniversitesi öğrencilerinin serbest zaman etkinliklerine katılım nedenleri ve değerlendirme biçimleri. Hacettepe Spor Bilimleri Dergisi, 20(4), 132-144.

Yeşilyurt, E. (2019). Eğitim fakültesi lisans programları ders öğrenme çıktılarının kazanımını etkileyen değişkenlerin etkisi ve nedenleri. Uluslararası Sosyal Araştırmalar Dergisi, 12, 904-925.

Yeşilyurt, E. ve Kurt, İ. (2012). Değerleri kazandırmasındaki etkililik açısından resmî ve örtük program ile okul dişı etmenlerin öğrenci görüşleri doğrultusunda değerlendirilmesi. Turkish Studies, 7, 3253-3272.

Yılmaz, A. (2019). Lise öğrencilerinin ders dışı sportif etkinliklere yönelik tutumları ile okula bağlanma durumlarının incelenmesi. Gaziantep Üniversitesi Spor Bilimleri Dergisi, 4(1), 50-63.

Yılmaz, A. ve Güven, Ö. (2018). Ders dışı sportif etkinliklere yönelik öğrenci tutum ölçeğinin psikometrik özelliklerinin incelenmesi (DSEÖTÖ). Journal of Human Sciences, 15(4), 1979-1992.

Doi: 10.14687/jhs.v15i4.5421

Yokuş, G., Ayçiçek, B. ve Yanpar Yelken, T. (2017). Üniversite öğrencilerinin yükseköğretim hizmet kalite algılarının ve kurumsal aidiyet düzeylerinin incelenmesi: Eğitim Fakültesi Örneği. Karaelmas Journal of Educational Sciences, 5, $1-18$.

Yozgat Bozok Üniversitesi (2018). Sınıf dışı etkinlik dersi yönergesi. https://bozok.edu.tr/sayfa/yonergeler,tr-163.aspx 